\title{
A Systematic Review of Intracellular Microorganisms within Acanthamoeba to Understand Potential Impact for Infection
}

\author{
Binod Rayamajhee ${ }^{1,2, *}$, Dinesh Subedi ${ }^{3}{ }^{\circledR}$, Hari Kumar Peguda ${ }^{1}\left(\right.$, Mark Duncan Willcox ${ }^{1}($, \\ Fiona L. Henriquez ${ }^{4}$ (D) and Nicole Carnt ${ }^{1}$ \\ 1 School of Optometry and Vision Science, University of New South Wales (UNSW), \\ Sydney, NSW 2052, Australia; h.peguda@unsw.edu.au (H.K.P.); m.willcox@unsw.edu.au (M.D.W.); \\ n.carnt@unsw.edu.au (N.C.) \\ 2 Department of Infection and Immunology, Kathmandu Research Institute for Biological Sciences (KRIBS), \\ Lalitpur 44700, Nepal \\ 3 School of Biological Sciences, Monash University, Clayton, VIC 3800, Australia; dinesh.subedi@monash.edu \\ 4 Institute of Biomedical and Environmental Health Research, School of Health and Life Sciences, \\ University of the West of Scotland (UWS), Paisley PA1 2BE, UK; fiona.henriquez@uws.ac.uk \\ * Correspondence: b.rayamajhee@unsw.edu.au or rayamajheebinod@gmail.com
}

check for updates

Citation: Rayamajhee, B.; Subedi, D.; Peguda, H.K.; Willcox, M.D.;

Henriquez, F.L.; Carnt, N. A

Systematic Review of Intracellular Microorganisms within Acanthamoeba to Understand Potential Impact for Infection. Pathogens 2021, 10, 225. https://doi.org/10.3390/pathogens 10020225

Academic Editor: María Reyes Batlle

Received: 31 January 2021

Accepted: 15 February 2021

Published: 18 February 2021

Publisher's Note: MDPI stays neutral with regard to jurisdictional claims in published maps and institutional affiliations.

Copyright: (c) 2021 by the authors. Licensee MDPI, Basel, Switzerland. This article is an open access article distributed under the terms and conditions of the Creative Commons Attribution (CC BY) license (https:/ / creativecommons.org/licenses/by/ $4.0 /)$.

\begin{abstract}
Acanthamoeba, an opportunistic pathogen is known to cause an infection of the cornea, central nervous system, and skin. Acanthamoeba feeds different microorganisms, including potentially pathogenic prokaryotes; some of microbes have developed ways of surviving intracellularly and this may mean that Acanthamoeba acts as incubator of important pathogens. A systematic review of the literature was performed in order to capture a comprehensive picture of the variety of microbial species identified within Acanthamoeba following the Preferred Reporting Items for Systematic Reviews and Meta-Analysis (PRISMA) guidelines. Forty-three studies met the inclusion criteria, 26 studies (60.5\%) examined environmental samples, eight (18.6\%) studies examined clinical specimens, and another nine $(20.9 \%)$ studies analysed both types of samples. Polymerase chain reaction (PCR) followed by gene sequencing was the most common technique used to identify the intracellular microorganisms. Important pathogenic bacteria, such as E. coli, Mycobacterium spp. and P. aeruginosa, were observed in clinical isolates of Acanthamoeba, whereas Legionella, adenovirus, mimivirus, and unidentified bacteria (Candidatus) were often identified in environmental Acanthamoeba. Increasing resistance of Acanthamoeba associated intracellular pathogens to antimicrobials is an increased risk to public health. Molecular-based future studies are needed in order to assess the microbiome residing in Acanthamoeba, as a research on the hypotheses that intracellular microbes can affect the pathogenicity of Acanthamoeba infections.
\end{abstract}

Keywords: Acanthamoeba; intracellular microbes; survival; carrier; co-infection

\section{Introduction}

Acanthamoeba, a ubiquitously distributed free-living amoeba, is known to cause a rare, but potentially sight-threatening, painful, often misdiagnosed, and difficult to treat corneal infection, keratitis, and meningoencephalitis, a fatal infection of the central nervous system (CNS) [1-5]. Acanthamoeba spp. can also cause sinusitis and cutaneous lesions in immunocompromised individuals, such as AIDS patients $[3,4,6]$. It has two distinct stages in its life cycle, an active phagotrophic trophozoite and a quiescent double walled cyst stage, with the cyst stage enabling the amoeba to remain viable for many years, even in harsh conditions, including chlorine treated water $[7,8]$. The infective form is the trophozoite stage, although both trophozoites and cysts can gain entry into the human body via different routes, such as debrided skin, cornea, and nasal passages [9]. Based on their morphology, Acanthamoeba species have been broadly classified into three groups (I, II, and III) [10] and pathogenic strains are common of group II [11]. Acanthamoeba species are 
also classified into at least 22 (T1-T22) genotypes based on their 18S rRNA sequences, with species, such as A. castellanii and A. polyphaga, within the T4 genotype frequently associated with corneal infection [12-14].

The Acanthamoeba trophozoite feeds on other microbes, such as bacteria, fungi, algae, and viruses, and can carry them intracellularly acting as "Trojan horse" $[15,16]$. Therefore, Acanthamoeba can act as a vector of potentially pathogenic microorganisms and, hence, play a role in pathogen dissemination as well as acting as a pathogen itself [17-19]. Both clinical and environmental isolates of Acanthamoeba harbour pathogenic prokaryotes as endosymbionts [20-22]. The term "endosymbiont" has been described as "a regulated, harmonious cohabitation of two nonrelated partners, in which one of them lives in the body of the other", and a bacterium is considered to be an endosymbiont when it is able to institute a replicative niche within, for example, eukaryotic cells [23]. However, another generic term "endocytobiont" has been coined to name the intracellular microbes that are associated with free-living amoeba to overcome any suggestion that the intracellular microbes might show mutualism, symbiosis, parasitism, phoresy, or zoochory [24,25]. Throughout the remainder of this review, the term "intracellular" will be used to encompass endosymbionts, endocytobionts, and other forms intracellular microbes within Acanthamoeba spp.

The detailed molecular pathways and strategies of intracellular interactions between Acanthamoeba and other microbes are unexplored at present. In a more generalised context, Acanthamoeba shares similar morphological and ultrastructural features to macrophages and they have a similar mechanism of interaction with microbes [26]. Amoeba may possess universal classes of receptors which bind with a wide array of microbial receptors facilitating adhesion and engulfment of a diverse range of microbes, such as Gal/GalNAc on Legionella pneumophila [27] or type III secretion structures on Vibrio parahaemolyticus [28] and E. coli K1 $[29,30]$ (Figure 1). If the engulfed microbes can then escape the normal phagosome-associated feeding pathway, they may exist intracellular [18]. The ability of microbes to set up an intracellular lifestyle in Acanthamoeba and remain viable has been hypothesised to allow them to subsequently live intracellularly in mammalian cells [31,32]. The intracellular survival mechanisms of bacteria in the amoebal cytoplasm differ between species and this, coupled with analysis of phylogenetic lineages of intracellular bacteria, indicates the ability that has developed with time over the microbe's evolution [33]. For instance, $V$. cholerae can escape degradation by applying an intricate neutralising program that effectively neutralises changes to the $\mathrm{pH}$, digestive enzyme functions, and the production of reactive oxygen radicals that may otherwise destroy the bacteria [34]. On the other hand, L. pneumophila forms a membrane-enclosed microenvironment within the Acanthamoeba that is produced via the endoplasmic reticulum, membrane transporters, and fusion with other membrane-bound vesicles [35,36]. The intracellular survival and proliferation of bacteria in amoebal cells has been associated with enhanced resistance of bacteria to antimicrobials and increased bacterial pathogenicity [37]. Acanthamoeba containing intracellular bacteria, such as Pseudomonas, Mycobacterium, and Chlamydia, has demonstrated a more rapid cytopathic effect (CPE) in in vitro as compared to isolates without intracellular bacteria [21,38], showing enhanced amoebal pathogenic potential.

This systematic review examines the intracellular microorganisms in Acanthamoeba and compares the types of microbial species that were identified in environmental and clinical isolates of Acanthamoeba, and potential impact of intracellular microorganisms on Acanthamoeba keratitis. The major aims of this review are: (a) to determine the laboratory techniques that have been used for the isolation and identification of intracellular microbes in Acanthamoeba spp.; (b) to assess whether different ways of culturing Acanthamoeba affect the types of intracellular bacteria; (c) to examine which microbes are most commonly found inside Acanthamoeba spp.; and (d) to determine whether environmental and clinical isolates of Acanthamoeba harbor the same intracellular prokaryotes. 


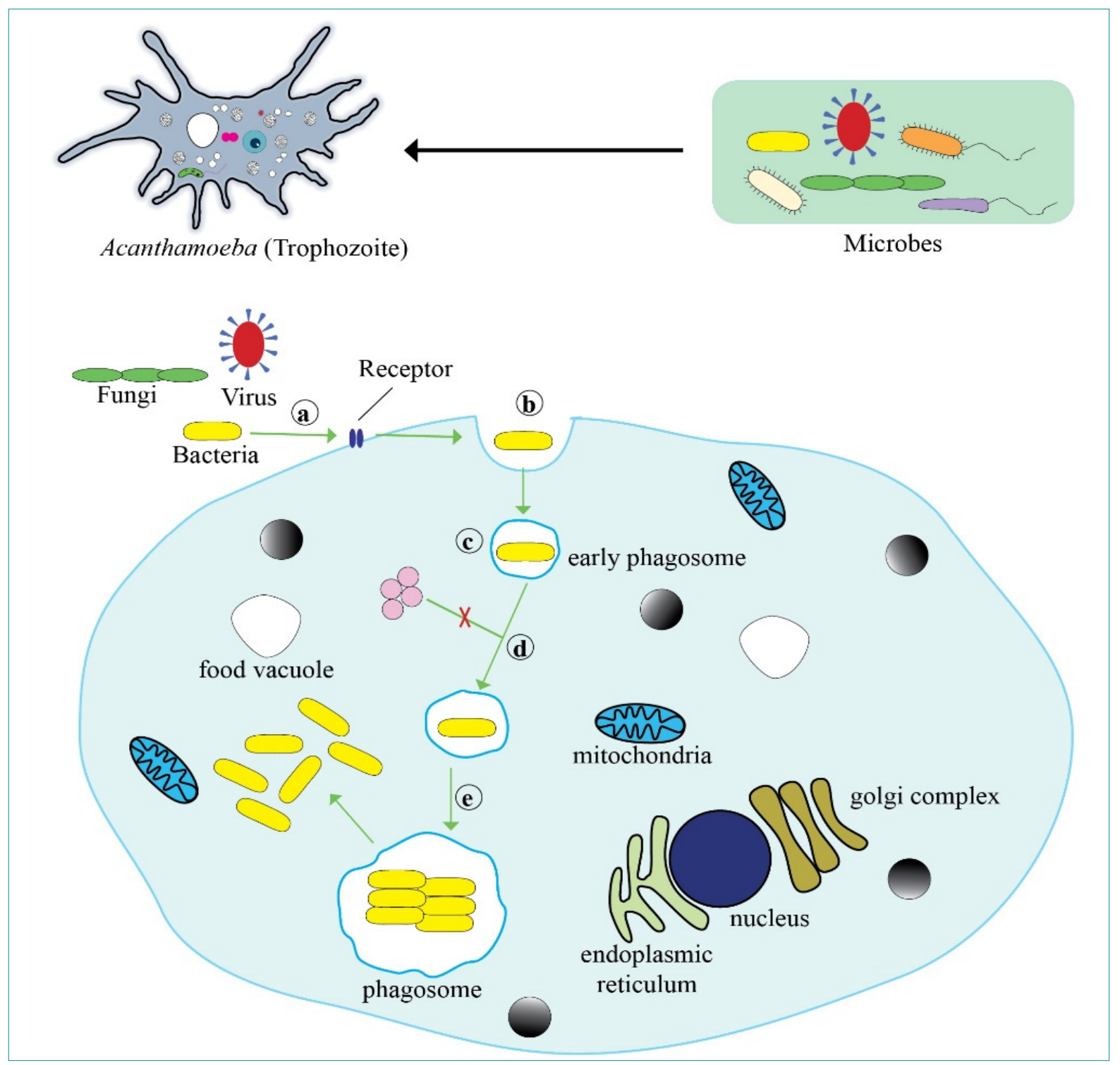

Figure 1. Representation of the different microorganisms as food of Acanthamoeba and interaction with bacteria. (a) attachment: possible receptor-mediated adhesion of bacteria; (b) entry: ingestion of bacteria using pseudopods and phagocytosis; (c) trafficking: prevention of phagosome-lysosome fusion by bacteria helps them evade lysosomal degradation and prevents acidification of the phagosomes [39]; (d) spread: vacuoles containing microbes disperse throughout the amoebal cytoplasm; and (e) replication: intraphagosomal replication of bacteria possible eventual escape into the amoebal cytoplasm.

\section{Results}

\subsection{Results of the Search}

The electronic search identified 1331 articles (PubMed $=234$, Scopus $=704$, WoS $=393$ ). After the removal of duplicates $(n=138), 1193$ articles were screened based on their titles and abstracts. The outcome was that 43 studies met the inclusion criteria. Figure 2 depicts the screening process.

\subsection{Included Studies}

In total, 43 studies were analysed. The study location, sample type, laboratory methods used, species and genotypes of Acanthamoeba strains, types of intracellular microbes, and co-occurrence of multiple microorganisms were examined. Brief details of each study included in the analysis are mentioned in Table 1. 
Table 1. Intracellular microorganisms identified in environmental and clinical isolates of Acanthamoeba species.

\begin{tabular}{|c|c|c|c|c|c|}
\hline Country, Date of Study & $\begin{array}{c}\text { Analysed Sample } \\
\text { (Clinical/Environmental) }\end{array}$ & Laboratory Investigation & $\begin{array}{l}\text { Positive Samples } \\
\text { for Intracellular } \\
\text { Microbes }\end{array}$ & $\begin{array}{l}\text { Species and Genotypes } \\
\text { of Acanthamoeba }\end{array}$ & Identified Intracellular Microbes \\
\hline USA, 1993 [20] & $\begin{array}{l}\text { Clinical (corneal-19, } \\
\text { and contact lens-4), } \\
\text { environmental specimens } \\
\text { (soil, forest detritus, lake and } \\
\text { stream sediments, pond } \\
\text { water, tree bark, potting soil, } \\
\text { 25), and ATCC strains (9) }\end{array}$ & $\begin{array}{l}\text { Culture, electron } \\
\text { microscopy, staining }\end{array}$ & 14 of 57 & $\begin{array}{c}\text { ATCC strains: } \\
\text { A. culbertsoni } 30886, \\
\text { 30011, and } 30868 \\
\text { A. rhysodes } 30973, \\
\text { A. polyphaga } 30871 \text { and } 30461 \\
\text { A. astronyxis } 30137, \\
\text { A. hatchetti } 30730, \\
\text { A. palestinensis } 30870, \\
\text { Acanthamoeba strain } 30173\end{array}$ & $\begin{array}{l}\text { Gram-negative rods and cocci and } \\
\text { non-acid fast non-motile bacteria }\end{array}$ \\
\hline Philippines, 1995 [40] & Pond & $\begin{array}{c}\text { Culture, PCR, } \\
\text { electronic microscopy }\end{array}$ & 1 of 1 & Acanthamoeba sps & $\begin{array}{l}\text { Gram-negative rod-shaped bacteria, } \\
\qquad 1.3 \times 0.43 \mu \mathrm{m} \text { in size }\end{array}$ \\
\hline South Korea, 1997 [41] & Contact lens storage & PCR, TEM & 1 of 1 & A. lugdunesis & Rod-shaped bacteria, $1.38 \times 0.5 \mu \mathrm{m}$ in size \\
\hline Germany, 1997 [42] & Nasal mucosa of humans & $\begin{array}{l}\text { Culture, electron microscopy, in } \\
\text { situ hybridization }\end{array}$ & 2 of 2 & $\begin{array}{l}\text { Acanthamoeba spp. and } \\
\text { A. mauritaniensis }\end{array}$ & $\begin{array}{l}\text { Coccoid shaped related to Chlamydia spp.; } \\
\text { Ca. Parachlamydia acanthamoebae } \\
\text { (proposed name for strain Bn9) }\end{array}$ \\
\hline Germany, 1998 [44] & $\begin{array}{l}\text { Cold water tap of a hospital } \\
\text { plumbing system }\end{array}$ & $\begin{array}{l}\text { Culture, electron microscopy, } \\
\text { gas-liquid chromatography }\end{array}$ & 1 of 1 & $\begin{array}{l}\text { Acanthamoeba spp. } \\
\text { Group II (K62) }\end{array}$ & Legionella-like slender rods \\
\hline Germany, 1998 [45] & Potable water reservoir & Culture, electron microscopy & 1 of 1 & Acanthamoeba sps Group II & $\begin{array}{l}\text { Archaea like (short rod shaped, } \\
1-1.5 \mu \mathrm{m} \text { length) endoparasite }\end{array}$ \\
\hline Germany, 1999 [46] & $\begin{array}{l}\text { Drinking water system } \\
\text { of a hospital }\end{array}$ & $\begin{array}{c}\text { Culture, phase contrast and } \\
\text { electron microscopy, gas-liquid } \\
\text { chromatography, Gram staining, } \\
\text { biochemical tests }\end{array}$ & 1 of 1 & Acanthamoeba spp. Group II & Cytophaga spp. (K69i) \\
\hline Germany, 1999 [47] & $\begin{array}{l}\text { Two clinical isolates (HN-3 } \\
\text { and UWC9) and one } \\
\text { environmental } \\
\text { isolate (UWE39) }\end{array}$ & $\begin{array}{l}\text { Culture, PCR, Gram and Giemsa } \\
\text { staining, sequencing, electron } \\
\text { microscopy, FISH, confocal laser } \\
\text { scanning microscopy (CLSM) }\end{array}$ & 3 of 3 & $\begin{array}{l}\text { Acanthamoeba spp. } \\
\text { (UWC9 and UWE39); } \\
\text { A. polyphaga (HN-3) [20] }\end{array}$ & $\begin{array}{c}\text { Ca. Caedibacter acanthamoebae } \\
\text { (proposed name); } \\
\text { Ca. Paracaedibacter acanthamoebae } \\
\text { (proposed name); Ca. Paracaedibacter } \\
\text { symbiosus (proposed name) }\end{array}$ \\
\hline
\end{tabular}


Table 1. Cont.

\begin{tabular}{|c|c|c|c|c|c|}
\hline Country, Date of Study & $\begin{array}{c}\text { Analysed Sample } \\
\text { (Clinical/Environmental) }\end{array}$ & Laboratory Investigation & $\begin{array}{l}\text { Positive Samples } \\
\text { for Intracellular } \\
\text { Microbes }\end{array}$ & $\begin{array}{l}\text { Species and Genotypes } \\
\text { of Acanthamoeba }\end{array}$ & Identified Intracellular Microbes \\
\hline USA, 1999 [48] & Corneal scraping & $\begin{array}{l}\text { Culture, Gram and Giemsa } \\
\text { staining, confocal laser-scanning } \\
\text { microscopy, PCR amplification, } \\
\text { sequencing of } \\
\text { 16S rRNA gene, EM }\end{array}$ & 2 of 2 & $\begin{array}{l}\text { Acanthamoeba species } \\
\text { (UWC8 and UWC36) }\end{array}$ & $\begin{array}{l}\text { Phylogenetically related to members of the } \\
\text { order Rickettsiales branch of the alpha } \\
\text { subdivision of the Proteobacteria ( } 99.6 \% \\
\text { sequence similarity to each other), Ca. } \\
\text { Midichloriaceae family in Rickettsiales }\end{array}$ \\
\hline USA, 2000 [49] & $\begin{array}{l}\text { Clinical (corneal tissues-1), } \\
\text { and environmental isolates } \\
\text { (soil samples from the } \\
\text { USA-1, and sewage sludge } \\
\text { from Germany-1) }\end{array}$ & $\begin{array}{l}\text { Culture, Giemsa staining, FISH, } \\
\text { electron microscopy, } \\
\text { PCR, sequencing }\end{array}$ & 4 of 4 & Acanthamoeba spp. & $\begin{array}{c}\text { Gram-negative cocci, may represent } \\
\text { distinct species of Parachlamydiaceae } \\
\text { Ca. Protochlamydia } \\
\text { amoebophila (UWE25) [50] }\end{array}$ \\
\hline Greece, 2000 [51] & $\begin{array}{l}\text { Water sample collected from } \\
\text { the drip-tray of the air } \\
\text { conditioning unit } \\
\text { of a hospital }\end{array}$ & $\begin{array}{l}\text { Culture, Gimenez } \\
\text { Staining, microscopy, PCR, 16S } \\
\text { rRNA sequencing }\end{array}$ & 1 of 1 & Acanthamoeba sps & $\begin{array}{l}\text { Ca. Odyssella thessalonicensis' gen. } \\
\text { nov., sp. nov. [gram negative, rod, and } \\
\text { motile] (proposed name); Note: The } \\
\text { phylogenetic position, inferred from } \\
\text { comparison of the } 16 \mathrm{~S} \text { rRNA gene } \\
\text { sequence, is within the } \alpha \text {-Proteobacteria. }\end{array}$ \\
\hline Germany, 2001 [52] & $\begin{array}{l}\text { Drinking water in a hospital, } \\
\text { corneal scrapings of a } \\
\text { keratitis patients (Germany) } \\
\text { and eutrophic lake } \\
\text { sediment (Malaysia) }\end{array}$ & $\begin{array}{l}\text { Culture, phase contrast and } \\
\text { electron microscopy, PCR, } 16 S \\
\text { rRNA sequencing }\end{array}$ & 3 of 3 & Acanthamoeba spp. T4 & $\begin{array}{c}\text { Flavobacterium succinicans (99\% 16S rRNA } \\
\text { sequence similarity) or Flavobacterium } \\
\text { johnsoniae (98\% 16S rRNA } \\
\text { sequence similarity); } \\
\text { Cytophaga-Flavobacterium-Bacteroides (CFB) } \\
\text { phylum (<82\% 16S rRNA sequence } \\
\text { similarity); Ca. Amoebophilus asiaticus } \\
\text { (proposed name) }\end{array}$ \\
\hline Germany, 2002 [53] & $\begin{array}{l}\text { Clinical and environmental } \\
\text { isolates from the } \\
\text { USA and Malaysia }\end{array}$ & $\begin{array}{l}\text { Culture, Gram, Giemsa and } \\
\text { DAPI staining, electron } \\
\text { microscopy, FISH, PCR, } 16 \mathrm{~S} \text { and } \\
23 \mathrm{~S} \text { rDNA-based sequencing }\end{array}$ & 6 of 6 & $\begin{array}{c}\text { A. polyphaga strain Page } 23 \\
\text { and Acanthamoeba spp. }\end{array}$ & $\begin{array}{l}\text { Rod-shaped Gram-negative obligate } \\
\text { bacterial endosymbionts, related to the } \\
\beta \text {-Proteobacteria: Ca. Procabacter } \\
\text { acanthamoebae' gen. nov., sp. nov. } \\
\text { (proposed name) }\end{array}$ \\
\hline
\end{tabular}


Table 1. Cont.

\begin{tabular}{|c|c|c|c|c|c|}
\hline Country, Date of Study & $\begin{array}{c}\text { Analysed Sample } \\
\text { (Clinical/Environmental) }\end{array}$ & Laboratory Investigation & $\begin{array}{l}\text { Positive Samples } \\
\text { for Intracellular } \\
\text { Microbes }\end{array}$ & $\begin{array}{l}\text { Species and Genotypes } \\
\text { of Acanthamoeba }\end{array}$ & Identified Intracellular Microbes \\
\hline France, 2003 [54] & Water of cooling tower & $\begin{array}{l}\text { Gram staining, electronic } \\
\text { microscopy, genome sequencing }\end{array}$ & 1 of 1 & A. polyphaga & Mimivirus \\
\hline South Korea, 2007 [55] & Contact lens storage case & $\begin{array}{l}\text { Culture, MtDNA RFLP analysis, } \\
\text { TEM, PCR, sequencing, AFB, and } \\
\text { fluorescent staining }\end{array}$ & 1 of 1 & A. lugdunensis & Mycobacterium spp. \\
\hline Austria, 2007 [57] & Lake & $\begin{array}{l}\text { Culture, FISH, TEM, PCR, 16S } \\
\text { rRNA sequences }\end{array}$ & 1 of 1 & Acanthamoeba sps T4 & $\begin{array}{c}\text { Ca. procabacter sp. OEW1 (proposed } \\
\text { name); Parachlamydia acanthamoebae Bn9 }\end{array}$ \\
\hline Spain, 2007 [58] & Tap water samples & Culture, PCR & 34 of 236 & $\begin{array}{c}\text { Acanthamoeba spp. T2; T3; T4; } \\
\text { T6 and T7 }\end{array}$ & $\begin{array}{c}\text { Human adenoviruses (HadV); serotypes } \\
\text { HadV-1, 2, 8, and } 37\end{array}$ \\
\hline Germany, 2008 [59] & $\begin{array}{l}\text { Contact lens and storage } \\
\text { case fluid }\end{array}$ & $\begin{array}{l}\text { Culture, light and } \\
\text { electron microscopy }\end{array}$ & 1 of 1 & $\begin{array}{l}\text { 1. A.triangularis } \\
\text { 2. Not yet determined, with } \\
\text { polygonal cysts }\end{array}$ & Pandoravirus inopinatum [60] \\
\hline Austria, 2008 [33] & $\begin{array}{l}\text { Soil and lake sediment } \\
\text { samples from Austria, } \\
\text { Tunisia, and } \\
\text { Dominica }(\mathrm{N}=10)\end{array}$ & $\begin{array}{l}\text { Culture, TEM and confocal laser } \\
\text { scanning microscopy, PCR, } \\
\text { genotyping, sequencing }\end{array}$ & 8 of 10 & $\begin{array}{c}\text { Acanthamoeba spp. (isolates } \\
\text { EI1, EI2, EI3, 5a2, EIDS3, and } \\
\text { EI6) }=\mathrm{T} 4 \text { and (isolates EI4 } \\
\text { and EI5) = T2 }\end{array}$ & $\begin{array}{l}\text { Parachlamydia sp. isolate Hall's coccus; } \\
\text { Protochlamydia amoebophila UWE25; } \\
\text { Ca. Paracaedibacter acanthamoebae } \\
\text { (proposed name); Ca. Amoebophilus } \\
\text { asiaticus TUMSJ-321 (proposed name); } \\
\text { Ca. Procabacter acanthamoebae Page23 } \\
\text { (proposed name); Parachlamydia sp. } \\
\text { isolate UV-7 }\end{array}$ \\
\hline South Korea, 2009 [61] & Tap water & $\begin{array}{c}\text { Culture, TEM and phase-contrast } \\
\text { light microscopy, PCR, } 16 \mathrm{~S} \mathrm{r} \\
\text { DNA sequencing }\end{array}$ & 5 of 17 & Acanthamoeba spp. & $\begin{array}{l}\text { Ca. Amoebophilus asiaticus (proposed } \\
\text { name); Ca. Odyssella thessalonicensis } \\
(\alpha-\text { Proteobacteria) (proposed name); } \\
\text { Methylophilus spp. }\end{array}$ \\
\hline
\end{tabular}


Table 1. Cont

\begin{tabular}{|c|c|c|c|c|c|}
\hline Country, Date of Study & $\begin{array}{c}\text { Analysed Sample } \\
\text { (Clinical/Environmental) }\end{array}$ & Laboratory Investigation & $\begin{array}{l}\text { Positive Samples } \\
\text { for Intracellular } \\
\text { Microbes }\end{array}$ & $\begin{array}{l}\text { Species and Genotypes } \\
\text { of Acanthamoeba }\end{array}$ & Identified Intracellular Microbes \\
\hline Japan, 2010 [62] & $\begin{array}{c}\text { Environmental samples } \\
\text { (41 soil samples: } 19 \text { river } \\
\text { water samples, } 4 \text { lake water } \\
\text { samples and } 2 \text { pond } \\
\text { water samples) }\end{array}$ & $\begin{array}{c}\text { Culture, PCR, sequencing, } \\
\text { FISH, TEM }\end{array}$ & 5 of 41 & $\begin{array}{c}\text { Acanthamoeba spp. T2; T4; } \\
\text { T6 and T13 }\end{array}$ & $\begin{array}{c}\text { Rod-shaped belonging to } \alpha \text { - and } \\
\beta \text {-Proteobacteria phyla; } \\
\text { sphere/crescent-shaped belonging to the } \\
\text { order chlamydiales } \\
\text { Protochlamydia; Neochlamydia [63] }\end{array}$ \\
\hline USA, 2010 [21] & $\begin{array}{l}\text { Acanthamoeba isolates }(\mathrm{N}=37) \\
\text { recovered from the cornea } \\
\text { and contact lens } \\
\text { paraphernalia of } 23 \text { patients, } \\
1 \text { environmental } \\
\text { (water) isolate }\end{array}$ & $\begin{array}{l}\text { Culture, PCR, sequencing, } \\
\text { FISH, TEM }\end{array}$ & 22 of 38 & Acanthamoeba spp. & $\begin{array}{l}\text { Legionella sp.; Pseudomonas sp.; } \\
\text { Mycobacterium sp.; Chlamydia sp. }\end{array}$ \\
\hline Spain, 2010 [64] & $\begin{array}{l}\text { Three different water } \\
\text { treatment plants }\end{array}$ & $\begin{array}{l}\text { Axenic culture, sequencing a } \\
\text { portion of the } 18 S \text { rRNA gene for } \\
\text { amoeba and specific } 16 \mathrm{~S} \text { rRNA } \\
\text { gene PCR for endosymbionts }\end{array}$ & 5 of 9 & Acanthamoeba T4 strain & Chlamydiae; Legionellae \\
\hline USA, 2011 [66] & $\begin{array}{l}\text { Eye infection, } \text { A. castellanii } \\
\text { strain Ma (ATCC 50370), } \\
\text { culture collection }\end{array}$ & $\begin{array}{l}\text { Culture, light microscopy, } \\
\text { PCR, sequencing }\end{array}$ & 1 of 1 & A. castellanii (ATCC 50370) & $\begin{array}{c}\text { Species of Mycobacterium avium complex } \\
\text { (MAC) (M. timonense; } \text { M. marseillense } \\
\text { and M. chimaera). }\end{array}$ \\
\hline UK, 2011 [67] & Sewage sludge & $\begin{array}{c}\text { Culture, PCR, sequencing of } \\
\text { Amoeba only }\end{array}$ & 1 of 1 & $\begin{array}{c}\text { A. palestinensis }(22 / 25 \text { clones }) \\
\text { within the T6 clade }\end{array}$ & Mimivirus-like particles \\
\hline Germany, 2013 [68] & $\begin{array}{l}\text { From biofilm of a flushing } \\
\text { cistern in a lavatory }\end{array}$ & $\begin{array}{l}\text { Culture, PCR, sequencing, } \\
\text { electron microscopy }\end{array}$ & 1 of 1 & Acanthamoeba spp. & $\begin{array}{l}\text { Stenotrophomonas maltophilia complex } \\
\quad(96.5 \% \text { sequence similarity) }\end{array}$ \\
\hline Japan, 2014 [69] & Hot Spring in Japan & $\begin{array}{l}\text { Culture, FISH, TEM, confocal } \\
\text { laser and phase-contrast } \\
\text { microscopy, PCR, sequencing }\end{array}$ & 1 of 1 & Acanthamoeba spp. T5 & Protochlamydia \\
\hline
\end{tabular}


Table 1. Cont

\begin{tabular}{|c|c|c|c|c|c|}
\hline Country, Date of Study & $\begin{array}{c}\text { Analysed Sample } \\
\text { (Clinical/Environmental) }\end{array}$ & Laboratory Investigation & $\begin{array}{l}\text { Positive Samples } \\
\text { for Intracellular } \\
\text { Microbes }\end{array}$ & $\begin{array}{l}\text { Species and Genotypes } \\
\text { of Acanthamoeba }\end{array}$ & Identified Intracellular Microbes \\
\hline Austria, 2014 [70] & Three environmental samples & $\begin{array}{l}\text { Axenic culture, PCR, } \\
\text { FISH, sequencing }\end{array}$ & 7 of 10 & $\begin{array}{c}\text { Acanthamoeba spp. (closely } \\
\text { related to A. castellanii Neff } \\
\text { GenBank Acc. U07416, } \\
\text { A. polyphaga) }\end{array}$ & $\begin{array}{l}\text { Paraceadibacter; Neochlamydia; } \\
\text { Protochlamydia; Procabacter; } \\
\text { Rickettsiales; Amoebophilus }\end{array}$ \\
\hline Brazil, 2015 [71] & $\begin{array}{l}\text { Seven samples from } \\
\text { air-condition units, and five } \\
\text { from contact lens cases }\end{array}$ & $\begin{array}{l}\text { Culture, FISH, semi nested-PCR, } \\
\text { DGGE, sequencing }\end{array}$ & 3 of 12 & $\begin{array}{l}\text { Acanthamoeba spp. T3; } \\
\text { T4 and T5 }\end{array}$ & $\begin{array}{c}\text { Paenibacillus spp., Ca. Protochlamydia } \\
\text { amoebophila, (uncultured } \gamma \text {-Proteobacterium) } \\
\text { (prposed name) }\end{array}$ \\
\hline Brazil, 2015 [72] & $\begin{array}{l}\text { Seven samples from } \\
\text { air-condition units, and five } \\
\text { from contact lens cases }\end{array}$ & $\begin{array}{l}\text { Axenic culture, conventional } \\
\text { PCR, amplicon sequencing }\end{array}$ & 12 of 12 & $\begin{array}{l}\text { Acanthamoeba spp. T3; } \\
\text { T4 and T5 }\end{array}$ & Pseudomonas spp. \\
\hline Japan, 2015 [73] & $\begin{array}{l}\text { Isolated from a } \\
\text { patient with AK }\end{array}$ & $\begin{array}{l}\text { Culture, Gram staining, } \\
\text { MicroScan autoSCAN-4 } \\
\text { system, PCR }\end{array}$ & 1 of 1 & Acanthamoeba strain $\mathrm{T} 4$ & E. coli \\
\hline Iran, 2015 [74] & Recreational water sources & $\begin{array}{l}\text { Axenic culture, staining, PCR, } \\
\text { genotyping, microscopy }\end{array}$ & 5 of 16 & Acanthamoeba spp. T4 and T5 & P. aeruginosa; Agrobacterium tumefaciens \\
\hline Spain, 2015 [75] & $\begin{array}{l}\text { Seventy water samples (three } \\
\text { DWTP, three wastewater } \\
\text { treatment plants and five } \\
\text { natural pools) }\end{array}$ & $\begin{array}{c}\text { Culture, PCR, } \\
\text { genotyping, sequencing }\end{array}$ & 43 of 54 & Acanthamoeba T3, T4 and T11 & Legionella spp. \\
\hline Japan, 2016 [76] & $\begin{array}{l}\text { Smear samples from } \\
\text { University Hospital }\end{array}$ & Culture, PCR, sequencing & 3 of 21 & Acanthamoeba spp. T4 & Protochlamydia spp.; Neochlamydia spp. \\
\hline Austria, 2016 [22] & $\begin{array}{l}\text { Corneal scraping of } \\
\text { AK patient }\end{array}$ & $\begin{array}{c}\text { Axenic culture, PCR, sequencing, } \\
\text { FISH, TEM }\end{array}$ & 1 of 1 & A. hatchetti, $\mathrm{T} 4$ & $\begin{array}{c}\text { Parachlamydia acanthamoebae; Candidatus } \\
\text { Paracaedibacter acanthamoebae } \\
\text { (proposed name) }\end{array}$ \\
\hline Austria, 2016 [77] & $\begin{array}{l}\text { Seventy-eight water samples } \\
\text { (66 cooling tower water: } 2 \\
\text { cooling towers of hospital, } 1 \\
\text { cooling tower of company, } \\
\text { and } 12 \text { tap water) }\end{array}$ & $\begin{array}{l}\text { Culture, FISH, real-time PCR, } \\
\text { genotyping, and sequencing }\end{array}$ & 3 of 53 & Acanthamoeba spp. T4 & $\begin{array}{l}\text { Paracaedibacter acanthamoebae; } \\
\text { Rickettsiales; L. pneumophila }\end{array}$ \\
\hline
\end{tabular}


Table 1. Cont.

\begin{tabular}{|c|c|c|c|c|c|}
\hline Country, Date of Study & $\begin{array}{c}\text { Analysed Sample } \\
\text { (Clinical/Environmental) }\end{array}$ & Laboratory Investigation & $\begin{array}{l}\text { Positive Samples } \\
\text { for Intracellular } \\
\text { Microbes }\end{array}$ & $\begin{array}{l}\text { Species and Genotypes } \\
\text { of Acanthamoeba }\end{array}$ & Identified Intracellular Microbes \\
\hline Canada, 2017 [78] & $\begin{array}{c}\text { Five clinical isolates (human } \\
\text { cornea, nasal swab, monkey } \\
\text { kidney tissue } \\
\text { Culture) and four } \\
\text { environmental isolates (lake } \\
\text { sediment, soil, and water } \\
\text { reservoir); all ATCC strains }\end{array}$ & $\begin{array}{l}\text { Axenic culture, amplifying and } \\
\text { sequencing of bacterial 16S DNA }\end{array}$ & 3 of 9 & $\begin{array}{c}\text { A. polyphaga } \\
\text { ATCC } 30173 \text { and 50495; } \\
\text { Acanthamoeba spp. PRA-220 }\end{array}$ & $\begin{array}{l}\text { Holosporaceae (Rickettsiales); } \\
\text { Mycobacterium spp.; Parachlamydia spp.; } \\
\text { Ca. procabacter sp. (proposed name) }\end{array}$ \\
\hline Malaysia, 2017 [79] & $\begin{array}{l}\text { Isolates from air-conditioning } \\
\text { outlets in wards and } \\
\text { operating theatres } \\
\text { (dust particles) }\end{array}$ & $\begin{array}{l}\text { Axenic culture, PCR, } \\
\text { genotyping, sequencing }\end{array}$ & 29 of 36 & Acanthamoeba spp. & $\begin{array}{c}\text { Mycobacterium spp. (M. fortuitum, M. } \\
\text { massiliense, M. abscessus, M. vanbaalenii, M. } \\
\text { senegalense, M. trivial and M. vaccae); } \\
\text { Legionella spp. (L. longbeachae, L. } \\
\text { wadwaorthii, L. monrovica, L. massiliensis and } \\
\text { L. feeleii); Pseudomonas spp. (P. stutzeri; } \\
\text { P. aeruginosa; P. denitrificans; P. chlororaphis } \\
\text { and P. knackmussi) }\end{array}$ \\
\hline Iran, 2019 [81] & $\begin{array}{l}\text { Corneal scrapes and contact } \\
\text { lenses isolate of } \\
\text { keratitis patients }\end{array}$ & $\begin{array}{l}\text { Culture, light microscopy, gram } \\
\text { staining, PCR, sequencing }\end{array}$ & 7 of 15 & Acanthamoeba spp. T4 & $\begin{array}{l}\text { E. coli; Achromobacter sps; P. aeruginosa; } \\
\text { Aspergillus sp.; Mastadenovirus sp.; } \\
\text { Microbacterium sp.; Stenotrophomonas } \\
\text { maltophilia; Brevundimonas vesicularis } \\
\text { and Brevibacillus sp. }\end{array}$ \\
\hline
\end{tabular}

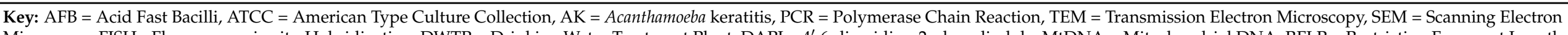

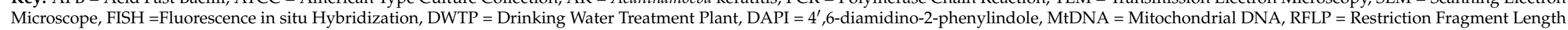
Polymorphism, DGGE = Denaturing Gradient Gel Electrophoresis, $\mathrm{Ca} .=$ Candidatus. 

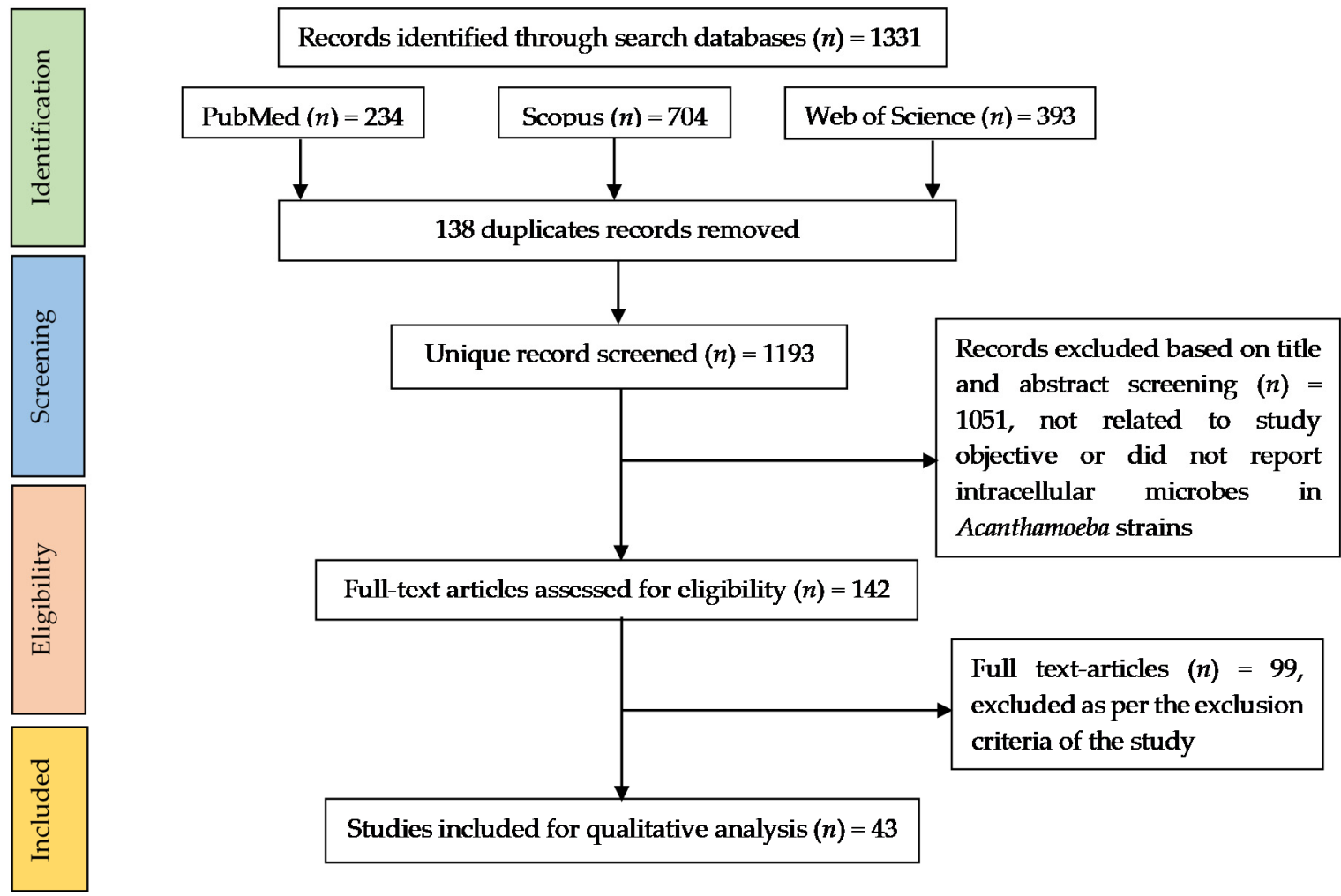

Figure 2. Preferred Reporting Items for Systematic reviews and Meta-Analyses (PRISMA) flow diagram for selection of articles.

2.3. Laboratory Techniques Used for the Isolation and Identification of Intracellular Microbes in Acanthamoeba spp.

Microbial culture, fluorescence in situ hybridization (FISH), microscopy, polymerase chain reaction (PCR), gene sequencing, and gas liquid chromatography were the laboratory techniques used for the identification of Acanthamoeba and associated intracellular microbes [21,22,33,48,50,55,56,61,72,74,76]. Two studies used gas-liquid chromatography to detect cellular fatty acids of intracellular bacteria and the identification was performed using Microbial Identification Inc. protocols (MIDI) (Newark, DE, USA) [44,46]. PCR $(33 / 43,76.7 \%)$, gene sequencing $(30 / 43,69.8 \%)$, and microscopy (transmission and scanning electron microscopy, confocal laser scanning, and phase-contrast microscopy) $(29 / 43,67.4 \%)$ were the most commonly used techniques to identify the amoeba and intracellular microbes, followed by fluorescence in situ hybridization $(12 / 43,27.9 \%)$ (Figure S1) [21,49,52,53,62,68,74,77]. Two studies observed intracellular bacteria in Acanthamoeba cysts $[52,80]$.

\subsection{Culture Techniques Used to Isolate and Identify Acanthamoeba}

Acanthamoeba can be axenically cultured [82], which means a culture in which only a single species is present entirely free from other contaminating organisms, i.e., with no food organisms, or by adding live or dead microbes to stimulate the growth of trophozoites $[15,83,84]$. Samples (clinical or environmental) are cultured on non-nutrient agar (NNA) covered with bacteria where amoebae graze and move away from the inoculation point in order to recover the symbiont with its natural amoeba host [85]. Axenic culture medium that supports Acanthamoeba growth consists of protease peptone, yeast extract, glucose $(\mathrm{PYG})$, and inorganic salts $\left(\mathrm{MgSO}_{4} \times 7 \mathrm{H}_{2} \mathrm{O}\right.$, sodium citrate dihydrate $\times 2 \mathrm{H}_{2} \mathrm{O}$, $\left.\mathrm{Na}_{2} \mathrm{HPO}_{4} \times 7 \mathrm{H}_{2} \mathrm{O}, \mathrm{KH}_{2} \mathrm{PO}_{4}, \mathrm{Fe}\left(\mathrm{NH}_{4}\right)_{2}\left(\mathrm{SO}_{4}\right)_{2} \times 6 \mathrm{H}_{2} \mathrm{O}\right)$ [86,87]. A wide range of bacteria have been used in co-culture with Acanthamoeba. The most common microbes used to 
culture Acanthamoeba are E. coli, Klebsiella aerogenes [88-90] and Enterobacter spp. (E. cloacae and E. aerogenes) $[8,25,59]$ on NNA or in saline [83] (Figure 3). It is not entirely clear why E. coli or K. aerogenes are the most commonly used as food supplement for culturing Acanthamoeba spp. There are only a few studies examining whether Gram negative or Gram positive are preferred or whether bacterial preference is dependent on amoebal species or genotypes [88]. One such study has shown that Acanthamoeba grows better on E. coli, Salmonella enterica serovar Typhimurium, or Bacillus subtilis than Enterococcus faecalis or Staphylococcus aureus [91].

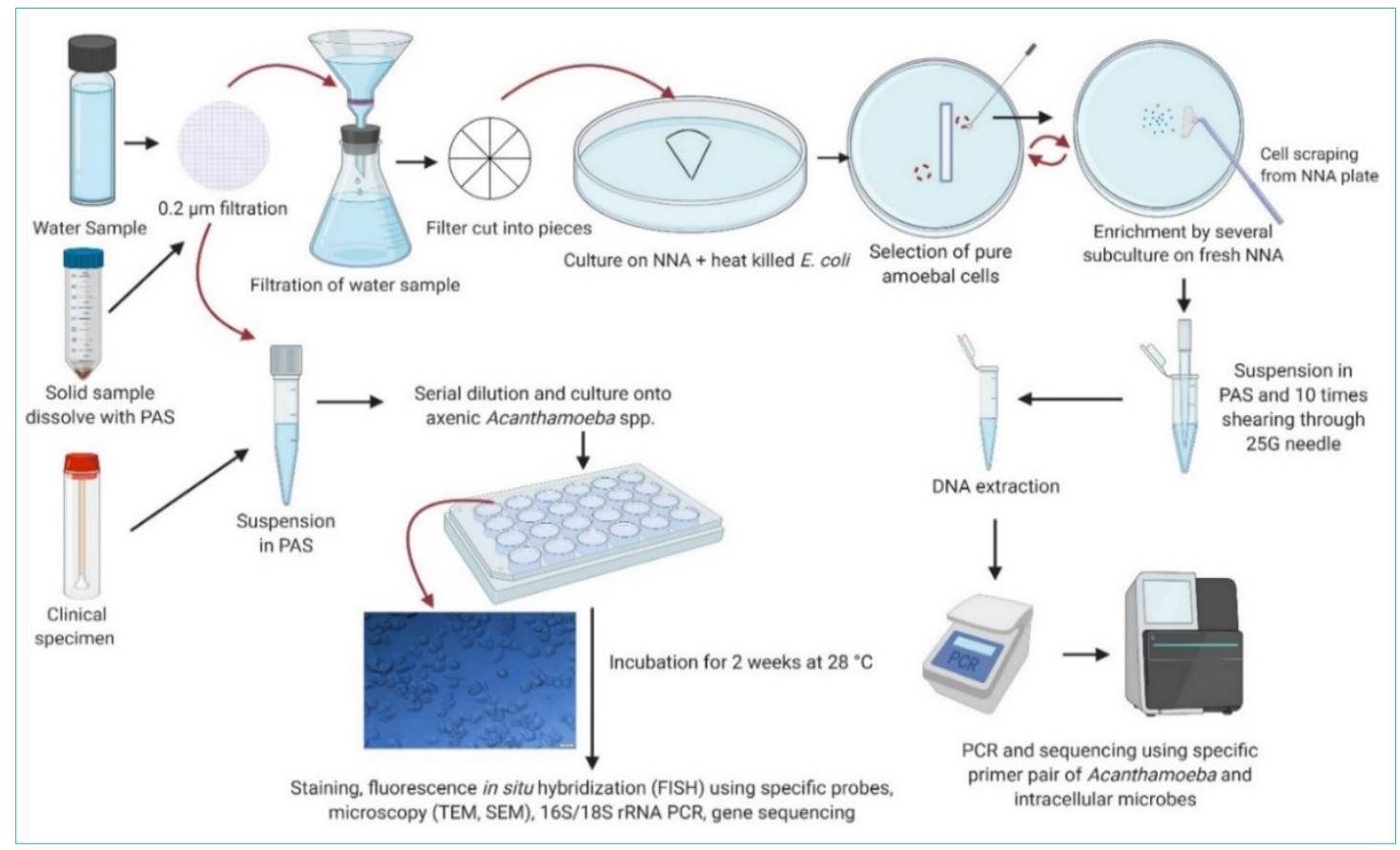

Figure 3. Laboratory procedures for the isolation and identification of Acanthamoeba and associated intracellular microorganisms from clinical and environmental samples. Adapted from Thomas et al. (2010) [37]. PAS: Page's Amoeba Saline, NNA: Non-nutrient agar, TEM = Transmission Electron Microscopy, SEM = Scanning Electron Microscope. Created with BioRender.com (accessed on 20 January 2021).

The bacteria used are commonly heat-killed [86,92] or heat-inactivated $[56,62]$ and spread upon NNA plates [70]. The use of bacteria, even dead bacteria, to grow Acanthamoeba trophozoites could potentially affect the types of intracellular microbes that can be grown from the Acanthamoeba. Twelve studies have examined the presence of intracellular bacteria using axenic culture $[22,43,46,51,66,69,71,72,78-80]$, where three studies [58,71,72] have used antibiotics (streptomycin, penicillin, and gentamicin) in PYG to grow amoebae axenically, 18 studies have used NNA with live/inactivated or killed bacteria (E. coli, E. cloacae, S. cerevisiae, E. aerogenes), followed by axenic culture, to recover the intracellular microbes harbouring Acanthamoeba [20,21,49,53,56,57,59,61,62,64,65,67,68,75-77,81] and antibiotics (penicillin, streptomycin, ampicillin, and amphotericin B) were added in culture media (NNA, TSB, SCGYE, PYG) to make the growth contamination free and axenic in another seven studies $[40,42,45,47,48,52,70]$ (Table 2). Some studies have used PYG without inorganic salts to maintain axenic growth of amoeba $[69,72]$. In the absence of established method for the recovery and identification of intracellular microbes of amoeba, different methods have been used to cultivate intracellular microorganisms carrying Acanthamoeba, which has shown inconsistent results. Pathogenic bacteria, such as Mycobacterium spp. [55,66,79] and Pseudomonas spp. [72,74,79], were often detected by axenic culture technique, whereas pathogenic intracellular bacteria belonging to the genera Legionella, Pseudomonas, Mycobacterium, and Chlamydia in clinical isolates of Acanthamoeba were detected by culturing on NNA pre-seeded with heat killed E. coli followed by axenic 
culture in 1X Page's saline solution [21]. Ten studies have used antibiotics at some point of cultivation to maintain the axenic culture and they have reported limited intracellular microorganisms as compared to studies grown Acanthamoeba on NNA supplemented with bacteria, where phylogenetically varied intracellular bacteria were repeatedly detected. In addition, axenic culture has been frequently used for clinical specimens (5/8) and NNA with pre-seeded bacteria was preferred to culture environmental samples $(22 / 26)$. Four serotypes of Adenovirus (Ad1, Ad2, Ad8, and Ad37) were detected in water-isolated Acanthamoeba by growing amoeba in PYG with gentamicin $(50 \mu \mathrm{g} / \mathrm{mL})[58]$.

The co-culture of environmental samples with symbiont-free Acanthamoeba as a surrogate host is being used as a new method to grow and recover facultative or obligate intracellular bacteria [93-95], but this method is not appropriate for isolating symbiont bacteria together with natural host.

Some bacteria have been examined for their ability to survive co-culture with Acanthamoeba. S. aureus can grow within A. polyphaga strain [91]. Shigella dysenteriae and S. sonnei were able to survive in co-culture with $A$. castellanii for $>3$ weeks [96] and mycobacterial strains related to $M$. intracellulare and $M$. avium for six years without any amoebal cytopathic effects [55]. Co-culture of $C$. jejuni with amoebal cells resulted in longer survival times as compared to bacteria grown alone [97]. C. jejuni and L. pneumophila were able to be resuscitated from a viable-but-nonculturable (VBNC) state when co-cultured with A. polyphaga or A. castellanii, respectively $[97,98]$. Acanthamoeba co-culture has been used to enrich low bacterial concentrations of four Campylobacter species, C. jejuni, C. lari, C. coli, and $C$. hyointestinalis [99]. VBNC P. aeruginosa can become culturable and active within $2 \mathrm{~h}$ of Acanthamoeba ingestion [100]. In vitro studies have shown A. castellanii can act as an important environmental reservoir of highly infectious bacteria, such as Francisella tularensis and $V$. cholerae [101,102]. Furthermore, V. cholerae survives within the contractile vacuole of amoeba, even upon the encystment and $F$. tularensis grows faster in co-culture with amoeba when compared to bacteria grown alone and causes rapid amoebal encystment [103]. Similarly, viable and intact growth of Helicobacter pylori is increased when co-cultured with A. castellanii [104]. Spores of a virulent B. anthracis (Ames strain with both pX01 and pX02 virulence plasmids, and Sterne strain with only pX01), an agent of bioterrorism, have shown a 50-times increase in spore count after $72 \mathrm{~h}$ of co-culture with A. castellanii. In addition, the spores were germinated within phagosomes of amoeba, with the Sterne strain showing less growth [105]. Pathogenic bacteria, such as A. baumannii, K. pneumoniae, and E. coli have been recovered from water samples by A. polyphaga coculture [93]. Acanthamoeba also promotes the survival and growth of fungi and viruses (Table 3), suggesting that Acanthamoeba can act as an environmental incubator for medically important prokaryotes and fungi.

Table 2. The types of microbes isolated from Acanthamoeba spp. using different culturing techniques.

\begin{tabular}{|c|c|c|c|}
\hline Culture Type & Source of Acanthamoeba & Identified Intracellular Organism in Acanthamoeba & Study \\
\hline \multirow{10}{*}{$\begin{array}{l}\text { Axenic culture on PYG, } \\
\text { KCM agar, NNA }(n=12)\end{array}$} & \multirow{3}{*}{ Clinical isolates } & Mycobacterium avium complex & [66] \\
\hline & & Escherichia coli & [73] \\
\hline & & $\begin{array}{l}\text { Parachlamydia acanthamoebae and } \\
\text { Ca. Paracaedibacter acanthamoebae }\end{array}$ & [22] \\
\hline & \multirow{7}{*}{ Environmental isolates } & Candidatus spp. & [51] \\
\hline & & Protochlamydia & [69] \\
\hline & & Burkholderia pickettii (biovar 2) & [43] \\
\hline & & Cytophaga spp. & [46] \\
\hline & & Mycobacterium spp. & [55] \\
\hline & & P. aeruginosa and Agrobacterium tumefaciens & [74] \\
\hline & & Mycobacterium spp. and Pseudomonas spp. & [79] \\
\hline
\end{tabular}


Table 2. Cont

\begin{tabular}{|c|c|c|c|}
\hline Culture Type & Source of Acanthamoeba & Identified Intracellular Organism in Acanthamoeba & Study \\
\hline & \multirow{2}{*}{$\begin{array}{l}\text { Clinical and environmental } \\
\text { (both) isolates }\end{array}$} & $\begin{array}{l}\text { Rickettsiales; Mycobacterium spp.; } \\
\text { Parachlamydia spp. and Ca. procabacter sp. }\end{array}$ & [78] \\
\hline & & Candidatus spp. & [80] \\
\hline \multirow{3}{*}{$\begin{array}{l}\text { Axenic culture in presence } \\
\text { of antibiotics }(n=3)\end{array}$} & \multirow{3}{*}{ Environmental isolates } & Human adenoviruses & [58] \\
\hline & & $\begin{array}{c}\text { Paenibacillus spp.; } \\
\text { Ca. Protochlamydia amoebophila; } \gamma \text {-Proteobacterium }\end{array}$ & [71] \\
\hline & & Pseudomonas spp. & [72] \\
\hline \multirow{18}{*}{$\begin{array}{l}\text { NNA with } \\
\text { live/inactivated/killed } \\
\text { bacteria }(n=18)\end{array}$} & \multirow[t]{2}{*}{ Clinical isolates } & $\begin{array}{l}\text { E. coli; Achromobacter sps; P. aeruginosa; Aspergillus sps; } \\
\text { Mastadenovirus; Microbacterium sps; Stenotrophomonas } \\
\text { maltophilia; Brevibacillus sps and Brevundimonas vesicularis }\end{array}$ & [81] \\
\hline & & $\begin{array}{c}\text { Caedibacter caryophilus and } \\
\text { Cytophaga-Flavobacterium-Bacteroides }\end{array}$ & [56] \\
\hline & \multirow{12}{*}{ Environmental isolates } & $\begin{array}{l}\text { Ca. Babela massiliensis, Alphaproteobacterium bacillus, } \\
\text { Mimivirus (Lentille), Virophage (Sputnik 2) }\end{array}$ & [65] \\
\hline & & Mimivirus-like particles & [67] \\
\hline & & Stenotrophomonas maltophilia complex & [68] \\
\hline & & Legionella spp. & [75] \\
\hline & & Ca. procabacter sp. and Parachlamydia acanthamoebae & [57] \\
\hline & & Protochlamydia spp. and Neochlamydia spp. & [76] \\
\hline & & Paracaedibacter acanthamoebae; Rickettsiales; L. pneumophila & [77] \\
\hline & & Pandoravirus & [59] \\
\hline & & $\begin{array}{c}\text { Parachlamydia sp.; } \\
\text { Protochlamydia amoebophila; Candidatus spp. }\end{array}$ & [33] \\
\hline & & Candidatus spp. & [61] \\
\hline & & $\alpha$ - and $\beta$-Proteobacteria and chlamydiales & [62] \\
\hline & & Chlamydiae; Legionellae & [64] \\
\hline & \multirow{4}{*}{$\begin{array}{l}\text { Clinical and environmental } \\
\text { (both) isolates }\end{array}$} & Gram-negative; rods and coccus; non-acid fast; non-motile & [20] \\
\hline & & Parachlamydiaceae and Ca. Protochlamydia amoebophila & [49] \\
\hline & & $\begin{array}{l}\text { Ca. Procabacter acanthamoebae' gen. nov., } \\
\text { sp. nov. (proposed) }\end{array}$ & [53] \\
\hline & & Legionella; Pseudomonas; Mycobacterium; Chlamydia & [21] \\
\hline \multirow{7}{*}{$\begin{array}{l}\text { Live/inactivated/killed } \\
\text { bacteria on } \\
\text { NNA/SCGYE/TSB/PYG } \\
\text { with antibiotics }(n=7)\end{array}$} & \multirow{2}{*}{ Clinical isolates } & Chlamydia spp. and Ca. Parachlamydia acanthamoebae & [42] \\
\hline & & Rickettsiales spp. & {$[48]$} \\
\hline & \multirow{3}{*}{ Environmental isolates } & Archaea like organism & [45] \\
\hline & & Gram-negative, rod-shaped bacteria & [40] \\
\hline & & $\begin{array}{l}\text { Paraceadibacter; Neochlamydia; Protochlamydia; } \\
\quad \text { Procabacter; Rickettsiales; Amoebophilus }\end{array}$ & [70] \\
\hline & \multirow{2}{*}{$\begin{array}{l}\text { Clinical and environmental } \\
\text { (both) isolates }\end{array}$} & Candidatus spp. & [47] \\
\hline & & Flavobacterium spp. and Ca. Amoebophilus asiaticus & [52] \\
\hline
\end{tabular}

Key: $\mathrm{PYG}=$ Peptone-yeast-glucose, $\mathrm{KCM}$ agar $=\mathrm{KCM}$ buffer $\left(\mathrm{KCl}, \mathrm{CaCl}_{2}\right.$ and $\left.\mathrm{MgSO}_{4} \cdot \mathrm{H}_{2} \mathrm{O}\right)$ in Bacto agar, NNA = non-nutrient agar, $\mathrm{TSB}=$ Tryptic soy-yeast extract broth, SCGYE = Serum-casein glucose yeast extract . 
Table 3. Interactions of fungi or viruses with Acanthamoeba spp.

\begin{tabular}{|c|c|c|c|}
\hline S.N. & Microorganisms & Interaction with Acanthamoeba spp. & Reference \\
\hline \multirow[t]{5}{*}{1.} & \multicolumn{3}{|c|}{ Fungi } \\
\hline & Histoplasma capsulatum & Co-culture with A. castellanii (ATCC 30324), cell lysis & [106] \\
\hline & C. neoformans & Intracellular multiplication in A. castellanii strain 30324 & [107] \\
\hline & Sporothrix schenckii & Co-culture with $A$. castellanii (ATCC 30324 ), cell lysis & [106] \\
\hline & Fusarium conidia & $\begin{array}{l}\text { Co-culture with different strains of } A \text {. castellanii (ATCC 30010, 50492), } \\
\text { germinate in amoebal cells }\end{array}$ & [108] \\
\hline \multirow[t]{3}{*}{2.} & \multicolumn{3}{|c|}{ Viruses } \\
\hline & $\begin{array}{c}\text { HAdV } \\
\text { Coxsackie virus }\end{array}$ & \multirow{2}{*}{$\begin{array}{c}\text { Co-culture with different isolates of Acanthamoeba, intracellular survival } \\
\text { Intracyst and intracellular survival in a clinical isolate of } A \text {. castellanii } \\
\text { Intracellular multiplication in } A \text {. polyphaga isolated from the water } \\
\text { sample of a cooling tower }\end{array}$} & $\begin{array}{l}{[58]} \\
{[109]}\end{array}$ \\
\hline & Mimivirus & & [54] \\
\hline
\end{tabular}

\subsection{Species and Genotypes of Acanthamoeba spp.}

The most commonly reported genotypes of Acanthamoeba are T4 [11,52,57,64,73,74,76,77,81], followed by T3 [58,69,71,72,75,80], T5 [69,72,80,110], and T2 [33,58,62,74] (Figure S2). A. polyphaga was detected in eight studies $[20,33,47,53,54,65,70,78]$ and A. castellani was observed in five studies $[20,33,56,66,70]$. A. hatchetti (T11, T4) [20,22] and A. palestinensis (T2, T6) $[20,67]$ were observed in two studies. Additionally, A. culbertsoni, A. astronyxis (T7) [20], A. lugdunesis [41], A. mauritaniensis [42], and Acanthamoeba T7 [58] and T11 [75] strains were also reported by single studies.

\subsection{The Types of Microorganisms Commonly Found Inside Acanthamoeba spp.}

Bacteria were the most commonly identified intracellular microorganism in Acanthamoeba followed by viruses and fungi (Figure S3). Unidentified bacteria, termed Candidatus, were reported in $1 / 3^{\text {rd }}$ of included studies $[22,33,42,47,50-53,57,61,65,69,72,77,78,80]$ and Chlamydia species were detected in 11 studies [21,33,42,49,57,62,64,69,70,76,78]. Five studies found Legionella spp. [21,44,64,75,79], another five studies reported Mycobacterium [21,55,66,78,79] or Pseudomonas spp. [21,71,74,79,81], four studies found Rickettsia spp. [48,77,78,111], three studies detected Cytophaga spp. [46,52,56], and E. coli [73,81] or Stenotrophomonas maltophilia $[68,81]$ were detected in two studies. Burkholderia pickettii [43], Agrobacterium tumefaciens [74], Brevibacillus sp. [81], Flavobacterium sp. [52], Brevundimonas vesicularis, or Microbacterium sp. [81] were also reported in single studies. Three studies only reported the morphology of intracellular "bacteria" present in Acanthamoeba $[20,40,41]$. An archaea-like organism was detected in the cytoplasm of Acanthamoeba recovered from a potable water reservoir [45].

Giant mimivirus was detected in three studies $[54,65,67]$, and human adenovirus (HAdV) was isolated in two studies [58,81]. The virophage sputnik 2 [65] and pandoravirus [59] were detected in the contact lens of AK patient in one study. Aspergillus was found in Acanthamoeba recovered from corneal scrapes and contact lenses of a keratitis patient in one study [81].

The presence of more than one intracellular microbe was reported in ten studies $[21,22,57,62,65,70,71,78,79,81]$. For example, Chlamydia and Legionella have been observed in a clinical isolate of Acanthamoeba, an environmental isolate that harboured Legionella and Mycobacterium [21], and Procabacter and Parachlamydia were found in Acanthamoeba (OEW1) isolated from a saline lake in Austria [57]. A study from Iran reported three intracellular microorganisms, P. aeruginosa, Aspergillus spp. and HAdV in a clinical isolate of Acanthamoeba T4 (ICS7) [81]. A. polyphaga isolated from a keratitis patient hosted four intracellular prokaryotes: Deltaproteobacterium, Alphaproteobacterium, mimivirus Lentille, and the virophage Sputnik 2 [65]. 


\subsection{Differences between the Intracellular Prokaryotes Found in Environmental and Clinical Isolates of Acanthamoeba}

Twenty-six studies (60.5\%) analysed environmental samples that were collected from soil, sewage sludge, water treatment plants, household tap water, recreational water sources, air conditioning units, hospital areas, such as operating theatres, and contact lens storage cases. Eight $(18.6 \%)$ studies processed specimens from patients, such as nasal or mucosal swabs, corneal scrapes/swabs or tissue, and AK patient's contact lenses, and these were grouped as clinical samples. Another nine studies (20.9\%) examined both types of samples (Figure S4 and Table 1).

Pathogenic bacteria, such as E. coli, Mycobacterium spp. and P. aeruginosa, were observed in Acanthamoeba strains that were cultured from clinical specimens $[21,66,73,81]$ (Table 4). Acanthamoeba spp. obtained from the corneas of patients contained obligate intracellular bacteria of the order Rickettsiales [48,111], E. coli [73], Pseudomonas, Chlamydia [21], Caedibacter caryophilus and Cytophaga-Flavobacterium-Bacteroides (CFB) [56]. The presence of bacteria in Acanthamoeba has been shown to exacerbate keratitis [21,112] and influence the virulence, pathogenicity, and susceptibility of keratitis causing amoeba to therapeutic drugs [55,75]. Chlamydia was observed in Acanthamoeba isolated from the nasal mucosa of volunteers [42] and presence of Pandoravirus inopinatum was confirmed in Acanthamoeba strain recovered from pieces of contact lenses worn by a keratitis patient [59,60].

Acanthamoeba carrying mimivirus and Legionella spp. were isolated from environmental samples that were collected from air-conditioning units, water treatment plants, and sewage sludge $[44,54,64,67,75]$. Contact lens cases, often cultured when a keratitis case presented for treatment, have been a rich source of intracellular microbes. Mimivirus strain Lentille, Sputnik 2 [65] and Mycobacterium sp. [55] have been isolated from contact lens storage cases. Even though contact lens cases are frequently exposed to disinfectants, several studies have shown that these disinfectants often have poor activity against Acanthamoeba spp. [113-115]. Hospital floor and sink swabs were found to be positive for Acanthamoeba with Chlamydia (14.3\%) showing the possibility of pathogen transmission via amoeba in the hospital setting [76]. Four different serotypes of human adenovirus (HAdV-1, $2,8,37)$ were found in $14.4 \%(34 / 236)$ of amoeba isolated from tap water [58]. P. aeruginosa and A. tumefaciens were detected in Acanthamoeba strains cultured from recreational water samples [74]. Acanthamoeba trophozoites and cysts are highly resistant to disinfectants used to decontaminate water supplies and the intracellular bacteria may be protected from these external disinfectants $[37,74,116]$.

Irrespective of the place of isolation, Acanthamoeba hosts many different pathogens [18] but endemically important human pathogens, such as E. coli, Pseudomonas spp. and Mycobacterium spp., were more commonly identified in Acanthamoeba cultured from clinical specimens, whereas giant viruses (mimivirus and Pandoravirus), Legionella spp., and unnamed bacteria of genus Candidatus were often detected in environmental Acanthamoeba. This suggests that most intracellular microbes interact with Acanthamoeba in their natural environment [117]. Acanthamoeba may act as a "Trojan horse" for microbes, providing them with the opportunity to colonise or infect different environments [118]. The ability of Acanthamoeba to host several different intracellular microbes suggests that these may interact with each other and lead to highly complex differences in the pathogenesis of Acanthamoeba [21]. 
Table 4. Intracellular microbes identified in Acanthamoeba spp. from clinical or environmental sources.

\begin{tabular}{|c|c|c|c|c|}
\hline Sample Type & Analysed Sample & Amoebal Host & $\begin{array}{l}\text { Identified Intracellular Pathogenic } \\
\text { Microbes in Acanthamoeba spp. }\end{array}$ & Study \\
\hline \multirow{11}{*}{$\begin{array}{c}\text { Clinical } \\
\text { specimens }\end{array}$} & \multirow{8}{*}{ Corneal specimens } & Acanthamoeba spp. & $\begin{array}{l}\text { Legionella, Pseudomonas; } \\
\text { Mycobacterium; } \\
\text { Chlamydia }\end{array}$ & [21] \\
\hline & & $\begin{array}{l}\text { A. castellanii } \\
\text { (ATCC 50370) }\end{array}$ & Mycobacterium avium complex (MAC) & {$[66]$} \\
\hline & & $\begin{array}{l}\text { A. polyphaga } \\
\text { (ATCC 50495) }\end{array}$ & Mycobacterium spp. & [78] \\
\hline & & Acanthamoeba spp. & Rickettsiales & {$[48,111]$} \\
\hline & & Acanthamoeba spp. T4 & $\begin{array}{l}\text { P. aeruginosa; Aspergillus spp.; } \\
\text { Mastadenovirus spp. }\end{array}$ & [81] \\
\hline & & A. castellanii $\mathrm{T} 4$ & $\begin{array}{c}\text { Caedibacter caryophilus; } \\
\text { Cytophaga-Flavobacterium-Bacteroides (CFB) }\end{array}$ & {$[56]$} \\
\hline & & A. hatchetti $\mathrm{T} 4$ & Parachlamydia acanthamoebae & [22] \\
\hline & & Acanthamoeba T4 & E. coli & {$[73,81]$} \\
\hline & \multirow{2}{*}{ Human nasal mucosa } & Acanthamoeba spp. & $\begin{array}{c}\text { Chlamydia sps; } \\
\text { Candidatus Parachlamydia acanthamoebae }\end{array}$ & [42] \\
\hline & & $\begin{array}{l}\text { A. polyphaga } \\
\text { (ATCC 30173) }\end{array}$ & Rickettsiales & [78] \\
\hline & Contact lens and fluid & $\begin{array}{l}\text { Acanthamoeba spp. } \\
\text { (A. triangularis) }\end{array}$ & Pandoravirus inopinatum & {$[59,60]$} \\
\hline \multirow{13}{*}{$\begin{array}{l}\text { Environmental } \\
\text { samples }\end{array}$} & Tap water & $\begin{array}{c}\text { Acanthamoeba } \\
(\mathrm{T} 2, \mathrm{~T} 3, \mathrm{~T} 4, \mathrm{~T} 6 \text {, and } \mathrm{T} 7)\end{array}$ & Human adenoviruses & [58] \\
\hline & $\begin{array}{c}\text { Recreational } \\
\text { water sources }\end{array}$ & Acanthamoeba (T4, T5) & P. aeruginosa; $A$. tumefaciens & [74] \\
\hline & $\begin{array}{l}\text { Water treatment plant, } \\
\text { natural pools }\end{array}$ & $\begin{array}{l}\text { Acanthamoeba } \\
(\mathrm{T} 3, \mathrm{~T} 4, \mathrm{~T} 11)\end{array}$ & Legionella spp. & {$[64,75]$} \\
\hline & $\begin{array}{l}\text { Sewage sludge and } \\
\text { cooling tower water }\end{array}$ & $\begin{array}{l}\text { A. palestinensis; } \\
\text { A. polyphaga }\end{array}$ & Mimivirus & {$[54,67]$} \\
\hline & \multirow[b]{2}{*}{$\begin{array}{l}\text { Contact lens storage } \\
\text { case/liquid }\end{array}$} & A. lugdunensis & Mycobacterium spp. & [55] \\
\hline & & A. polyphaga & $\begin{array}{l}\text { Deltaproteobacterium; Mimivirus Lentille; } \\
\text { Virophage Sputnik 2; } \\
\text { Alphaproteobacterium bacillus }\end{array}$ & [65] \\
\hline & Soil and lake sediment & $\begin{array}{l}\text { A. castellanii and } \\
\text { A. royreba } \mathrm{T} 4 ; \\
\text { A. pustulosa and } \\
\text { A. polyphaga } \mathrm{T} 2\end{array}$ & $\begin{array}{c}\text { Parachlamydia sp.; } \\
\text { Protochlamydia amoebophila; } \\
\text { Ca. Paracaedibacter acanthamoebae; } \\
\text { Ca. Amoebophilus asiaticus, } \\
\text { Ca. Procabacter acanthamoebae }\end{array}$ & {$[33]$} \\
\hline & $\begin{array}{l}\text { Biofilm of a flushing } \\
\text { cistern in a lavatory }\end{array}$ & Acanthamoeba spp. & Stenotrophomonas spp. & [68] \\
\hline & Hot Spring & Acanthamoeba spp. T5 & Protochlamydia & [69] \\
\hline & Hospital environment & Acanthamoeba spp. T4 & Protochlamydia spp.; Neochlamydia spp. & [76] \\
\hline & Tap water & Acanthamoeba spp. & $\begin{array}{c}\text { Ca. Amoebophilus asiaticus; } \alpha \text {-Proteobacteria; } \\
\text { Methylophilus sps }\end{array}$ & [61] \\
\hline & $\begin{array}{c}\text { Recreational } \\
\text { water sources }\end{array}$ & $\begin{array}{l}\text { Acanthamoeba spp. } \\
\text { T4 and T5 }\end{array}$ & P. aeruginosa and Agrobacterium tumefaciens & [74] \\
\hline & Lake water & Acanthamoeba sps T4 & $\begin{array}{l}\text { Parachlamydia acanthamoebae; } \\
\text { Ca. procabacter sp. }\end{array}$ & {$[57]$} \\
\hline
\end{tabular}




\section{Discussion}

This study systematically analysed 43 published studies assessing the reported intracellular microorganisms that were associated with clinical and environmental isolates of Acanthamoeba. PCR followed by gene sequencing and microscopy were the most common laboratory techniques used to identify the intracellular microbes. Potentially pathogenic bacteria, such as Mycobacterium spp., P. aeruginosa, Rickettsiales, and E. coli, were often detected in clinical isolates, while Legionella, human adenovirus, mimivirus, and uncategorised bacteria (Candidatus) were found in environmental isolates. It appeared that the niche from which Acanthamoeba had been isolated affected the types of intracellular microbes present, or perhaps affected the ability of particular Acanthamoeba strains to cause infections. This latter hypothesis is presented based on previous investigations that domestic water supplies and contact lenses that are exposed to water are risk factors for Acanthamoeba keratitis [5,119-121]. This suggests that water is the source of the infecting Acanthamoeba [122] and, perhaps, those strains that harbour particular intracellular microbes are more able to instigate corneal (or other) infections [21]. However, not all Acanthamoeba isolated from infections have been shown to harbour intracellular microbes, perhaps because their presence has not been analysed. Alternatively, the Acanthamoeba may expel resident intracellular microbes during the infectious process. These hypotheses require scientific investigation.

NNA with live/heat-inactivated/killed E. cloacae/E. coli was the most common method $(25 / 43)$ used for the recovery and identification of Acanthamoeba associated microorganisms $[21,33,56,68]$. A higher proportion of clinical specimens were cultivated using axenic (PYG, NNA, KCM agar) media, while NNA with bacteria was often used to culture environmental samples. Environmental samples may consist of more promiscuous microbes, thus the culture media with Acanthamoeba could enhance the recovery and isolation of intracellular bacteria [95]. The use of different bacterial strains to cultivate amoebal trophozoites could affect the intracellular bacteria that can be recovered from the Acanthamoeba since different bacteria affect trophozoite growth and encystment [83]. In addition, antibiotics have been used to eliminate live bacteria for the axenic cultivation of Acanthamoeba. However, this review supports that use of antibiotics in culture media to grow clinical or environmental Acanthamoeba axenically could inhibit amoebal symbionts and limits the recovery of multiple intracellular bacteria. Therefore, before the adaptation to axenic growth, Acanthamoeba spp. should be sub-cultured several times on NNA plates that were covered with heat-killed E. coli [70], even though Acanthamoeba may grow better with live bacteria than heat killed [83]. The use of live E. coli tolC knockout mutants on NNA without antibiotics improved the axenic growth of Acanthamoeba spp. and these amoebae had phylogenetically distinct intracellular bacteria [70]. There is a definite need to understand whether the food preferences of Acanthamoeba depend on its resident sites/species/genotypes or intracellular microbes or change the intracellular community of microbes. Information such as preference for bacterial consumption on growth of amoeba, time for cyst formation, and intracellular survival of bacteria during the cultivation of Acanthamoeba have not yet been reported. These dynamics of Acanthamoeba-bacteria interaction should be taken into consideration in future studies.

Phylogenetically unrelated intracellular microbes were found within the same isolate of Acanthamoeba in ten studies. The diversity of intracellular microbes suggests that their ability to exploit Acanthamoeba as a host has developed continually, independent of the phylogenetic lineage [31]. Intracellular microbes can be either in a stable or transient association. Long-term stable interactions have been observed between Acanthamoeba and $\alpha / \beta$ Proteobacteria, chlamydiae, M. avium subsp. paratuberculosis, and Bacteroidetes $[51,52,123]$. However, amoeba can release intracellular microbes in suitable environments [124]. Transient association has been reported for bacteria, such as E. coli O157:H7, L. pneumophila, among others $[39,125]$. Intracellular survival of enterohaemorrhagic E. coli O157:H7 in A. castellanii was reduced by Shiga toxins (Stx) that were produced by the bacterium [125]. Co-occurrence of phylogenetically different bacterial species in Acanthamoeba can provide 
an opportunity for lateral gene transfer between intracellular bacteria $[57,126]$. Multiplespecies association within the same host cell poses challenges to all intracellular microbes, such as competition for nutrients obtained from the host cell, while the interplay between intracellular microbes needs to be balanced to ensure the stability of the association [57]. In depth biochemical and genomic analysis are needed in future research to understand the details of the interactions.

Intracellular microbes have been detected in Acanthamoeba isolates that belong to genotypes T2-T7, T11, and T13 [33,47,56,58,62,69,75], whether the occurrence of intracellular microbial strains is, in some way, dependent with amoebal genotypes is still an unanswered question. Acanthamoeba hosts for a wide range of microbial species that can presumably, and especially if they are permanent residents, resist phagocytosis, survive, multiply, and endure intracellularly [127]. Whether this can train these intracellular bacteria to survive in other cells, such as human macrophages [31,128,129], perhaps by the exchange of genes with other intracellular microbes [130] or by genetic mutation requires further investigation. This hypothesis is further supported by Chlamydia species, which use the same strategies to interact with various different host cells and that likely evolved years ago during interaction with primitive unicellular eukaryotes [31]. From a clinical viewpoint, a better understanding of molecular mechanisms by which pathogenic bacteria can resist amoebal phagocytosis may allow for the design of future antibiotics and vaccines in the treatment of intracellular human bacterial pathogens.

\section{Methods}

The Preferred Reporting Items for Systematic reviews and Meta-Analyses (PRISMA) guidelines were followed for this systematic review [131].

\subsection{Search Strategy and Data Sources}

A systematic search was conducted using three electronic databases, PubMed (Medline), Scopus, and Web of Science (WoS), to identify peer-reviewed articles providing information on the types of intracellular microbes associated with Acanthamoeba spp. The literature search was performed using the key terms, "Free-living amoeba" OR "FLA" OR "Acanthamoeba" AND "Bacterial endosymbiont" /"Bacterial endocytobiont" OR "Intracellular Acanthamoeba Endosymbiosis" OR "Amoeba symbiosis" OR "Amoeba-resisting bacteria" as Combinations of Medical Subject Headings (MeSH). This results in searches of articles containing the words 'Acanthamoeba' AND "Endosymbiont" / Endocytobiont" OR "Acanthamoeba endosymbiosis" OR "Intracellular" OR "Symbiosis" OR "Free-living amoeba" OR "FLA" in their titles and/or abstracts. Additionally, a snow-ball sampling approach was applied while using the reference lists of the selected articles to expand the search. The search was limited to studies that were published in English language and full text articles published between 1 February 1993 to 30 July 2019.

\subsection{Inclusion Criteria}

For an article to be included in this study, it had to be peer-reviewed, available in full text, with its primary objective to isolate and identify intracellular microbes in clinical or environmental isolates of Acanthamoeba spp. However, case reports of Acanthamoeba with symbionts were included. A narrative review was performed for all of the selected studies.

\subsection{Exclusion Criteria}

Articles that were published in languages other than English, conference abstracts, institutional protocols, other review papers, in vitro studies on the co-culture of Acanthamoeba species with bacteria, or other microorganisms for the analysis of symbiosis and isolation of intracellular microbes from amoeba other than Acanthamoeba were excluded from the study. Additionally, the coincidental finding of Acanthamoeba and microbes in the same sample, but with no evidence of the other microbes being intracellular, were not included in this study. 


\subsection{Data Abstraction, Quality Assessment, and Appraise Risk of Bias in Individual Studies}

At first, two members of the review team screened all of the articles, as per the inclusion and eligibility criteria following PRISMA guidelines and excluded inappropriate articles after consultation with the other authors. Following the database search, studies were pooled and uploaded sequentially into EndNote version X9 (Clarivate Analytics, Philadelphia, PA, USA), then duplicate studies were removed from the list. The authors reviewed a selection of the articles to verify the selection methodology. Any discrepancies between the reviewers were resolved by consensus discussion amongst all of the reviewers. Variables of interest in the included studies were laboratory techniques that were used for the identification of microorganisms, detection and types of Acanthamoeba and associated intracellular microbial species, study location, type of sample analysed (clinical or environmental), co-occurrence of multiple intracellular microbes within a Acanthamoeba cell, and sequence similarity of detected microbes with reference strains.

The potential risk of bias was assessed with a raw score of quality, as per the NewcastleOttawa Scale (NOS) guidelines (adapted for cross-sectional and observational studies) for the appropriateness and aims of the study, method of sample collection, and laboratory identification of Acanthamoeba and intracellular microbes [132]. A final score was assigned to each study after consensus between the reviewers. NOS scores can vary from 0 to 9 , and studies, with an average score of $\geq 6$ were included for this review (Table S1) [133]. A metaanalysis of the studies was not performed due to a high level of heterogeneity. Therefore, a systematic analysis was performed. Relevant data were extracted from each study in customised datasheets. Because of the diversity in variables in each study, the assessment scale was primarily based on the methodological quality, Acanthamoeba identification and evidence of intracellular microbes. Figures were created using Origin Lab, Version 2018 (Northampton, MA, USA).

\subsection{Outcome Measurements}

The main outcome measure of this review was the types of intracellular microbes that were identified dwelling in Acanthamoeba species. The secondary outcome measures were the effect of culture techniques on the types of intracellular microbes recovered from Acanthamoeba and the type of intracellular microbes from environmental and clinical sources.

\section{Conclusions}

This study systematically reviewed articles on the types of intracellular microorganisms in Acanthamoeba. Acanthamoeba acts as an incubator and carrier of a wide range of microorganisms. The niche or home of the Acanthamoeba appears to affect the types of intracellular microbes. Chlamydia spp., E. coli, Rickettsiales, Pseudomonas spp., and Mycobacterium spp. were the most commonly reported microbes in Acanthamoeba that were cultured from clinical specimens and Legionella, human adenovirus, mimivirus, and bacteria of Candidatus group were detected in environmental Acanthamoeba. Human macrophage and Acanthamoeba share significant cellular and functional features, particularly phagocytic activity, so amoebal cells might train and serve as a preparatory arena for the pathogens to onset diseases in mammalian cells. Molecular-based future studies are expected to assess the microbiome composition residing in Acanthamoeba to view the role of amoeba as a universal host and evolutionary trigger of phylogenetically varied microorganisms.

\section{Limitations of the Study}

The major limitation of this review was the lack of meta-analysis due to heterogeneous variables among the included studies. Although the study used multiple search engines using keywords, the query string may not have short-listed all the relevant studies given the disparity in terminology, such as "endosymbiont", "endocytobiont", "endosymbiosis", "amoeba symbiosis", "intracellular bacteria", and "amoeba-resisting bacteria". Additionally, the use of different laboratory techniques to identify the intracellular microbes in the included studies may have biased the reported microbes. Many studies applied protocols 
to isolate and identify particular prokaryotes, rather than assessing the whole microbiome residing in Acanthamoeba, which may not represent all of the microorganisms present within the amoebal cell. This suggests the use of deep sequencing technique could help to identify the composition of amoebal microbiome.

Supplementary Materials: The following are available online at https:/ /www.mdpi.com/2076-0817 /10/2/225/s1. Supplementary file I (S1): Table S1: The Newcastle-Ottawa Scale (NOS) for assessing the quality of studies included in this review; Supplementary file II (S2): List of supplementary figures (S1-S4); Supplementary file III (S3): PRISMA 2009 checklist.

Author Contributions: Conceptualization of the study, B.R., N.C., M.D.W., F.L.H.; data selection and extraction, B.R.; analysis, B.R., analysis, editing, M.D.W., F.L.H., N.C., D.S., H.K.P.; writing—original draft preparation, B.R., D.S., M.D.W., N.C., F.L.H.; review and editing; M.D.W., N.C., F.L.H., D.S., H.K.P.; supervision: M.D.W., N.C. and F.L.H. All authors have read and agreed to the published version of the manuscript.

Funding: None of the authors received external funding for this research.

Institutional Review Board Statement: Not applicable.

Informed Consent Statement: Not applicable.

Data Availability Statement: The data presented in this study are available in Tables 1-3 and S1, and Figures S1-S4.

Acknowledgments: Authors acknowledge the assistance of an academic librarian of the University of New South Wales (UNSW), Sydney, Australia for guiding the search strategy in the databases. B.R. is recipient of the Tuition Fee Scholarship (UNSW, Sydney) for his doctor degree, with which this review was completed.

Conflicts of Interest: The authors declare no conflict of interest.

\section{Abbreviations}

$\begin{array}{ll}\text { ARMs } & \text { Amoeba-resistant microorganisms } \\ \text { ARB } & \text { Amoeba-resistant bacteria } \\ \text { CPE } & \text { Cytopathic effect } \\ \text { FLA } & \text { Free living amoeba } \\ \text { HAdV } & \text { Human adenovirus } \\ \text { PYG } & \text { Peptone-yeast-glucose medium } \\ \text { PRISMA } & \text { Preferred Reporting Items for Systematic reviews and Meta-Analyses } \\ \text { MATE } & \text { Multidrug and toxin extrusion } \\ \text { MBP } & \text { Mannose-binding protein } \\ \text { NOS } & \text { Newcastle-Ottawa Scale } \\ \text { NNA } & \text { Non-nutrient agar } \\ \text { NTM } & \text { Nontuberculous Mycobacterium } \\ \text { PYG } & \text { Peptone-yeast-glucose } \\ \text { SCGYE } & \text { Serum-casein glucose yeast extract } \\ \text { TSB } & \text { Tryptic soy-yeast extract broth } \\ \text { VBMC } & \text { Viable but non-culturable } \\ \text { WoS } & \text { Web of Science }\end{array}$

\section{References}

1. Neelam, S.; Niederkorn, J.Y. Pathobiology and immunobiology of Acanthamoeba keratitis: Insights from animal models. Yale J. Biol. 2017, 90, 261-268.

2. Goldschmidt, P.; Degorge, S.; Saint-Jean, C.; Year, H.; Zekhnini, F.; Batellier, L.; Laroche, L.; Chaumeil, C. Resistance of Acanthamoeba to classic DNA extraction methods used for the diagnosis of corneal infections. Br. J. Ophthalmol. 2008, 92, 112-115. [CrossRef] [PubMed]

3. Torno, M.S., Jr.; Babapour, R.; Gurevitch, A.; Witt, M.D. Cutaneous acanthamoebiasis in AIDS. J. Am. Acad. Dermatol. 2000, 42, 351-354. [CrossRef] 
4. Dunand, V.A.; Hammer, S.M.; Rossi, R.; Poulin, M.; Mary, A.; Doweiko, J.P.; DeGirolami, P.C.; Coakley, E.; Piessens, E.; Wanke, C.A. Parasitic sinusitis and otitis in patients infected with human immunodeficiency virus: Report of five cases and review. JClin. Infect. Dis. 1997, 25, 267-272. [CrossRef] [PubMed]

5. Rayamajhee, B.; Subedi, D.; Won, S.; Kim, J.J.Y.; Vijay, A.; Tan, J.; Henriquez, F.L.; Willcox, M.; Carnt, N.A.J.W. Investigating Domestic Shower Settings as a Risk Factor for Acanthamoeba Keratitis. Water 2020, 12, 3493. [CrossRef]

6. Friedland, L.R.; Raphael, S.A.; Deutsch, E.S.; Johal, J.; Martyn, L.J.; Visvesvara, G.S.; Lischner, H.W. Disseminated Acanthamoeba infection in a child with symptomatic human immunodeficiency virus infection. Paediatr. Infect. Dis. J. 1992, 11, 404-407. [CrossRef]

7. Visvesvara, G.S.; Moura, H.; Schuster, F.L. Pathogenic and opportunistic free-living amoebae: Acanthamoeba spp., Balamuthia mandrillaris, Naegleria fowleri, and Sappinia diploidea. FEMS. Immunol. Med. Microbiol. 2007, 50, 1-26. [CrossRef]

8. Schuster, F.L. Cultivation of pathogenic and opportunistic free-living amoebas. Clin. Microbiol. Rev. 2002, 15, 342-354. [CrossRef] [PubMed]

9. Centers for Disease Control and Prevention (CDC), Division of Foodborne, Waterborne, and Environmental Diseases (DFWED). Parasites-Acanthamoeba-Granulomatous Amoebic Encephalitis (GAE); Keratitis. Available online: https://www.cdc.gov/para sites/acanthamoeba/pathogen.html (accessed on 20 November 2020).

10. Siddiqui, R.; Khan, N.A. Biology and pathogenesis of Acanthamoeba. Parasites Vectors 2012, 5, 6. [CrossRef]

11. Xuan, Y.; Shen, Y.; Ge, Y.; Yan, G.; Zheng, S. Isolation and identification of Acanthamoeba strains from soil and tap water in Yanji, China. Environ. Health Prev. Med. 2017, 22, 58. [CrossRef]

12. Corsaro, D.; Walochnik, J.; Köhsler, M.; Rott, M.B. Acanthamoeba misidentification and multiple labels: Redefining genotypes T16, T19, and T20 and proposal for Acanthamoeba micheli sp. nov. (genotype T19). Parasitol. Res. 2015, 114, 2481-2490. [CrossRef]

13. Zhao, G.; Sun, S.; Zhao, J.; Xie, L.J. Genotyping of Acanthamoeba isolates and clinical characteristics of patients with Acanthamoeba keratitis in China. J. Med. Microbiol. 2010, 59, 462-466. [CrossRef]

14. Taher, E.E.; Méabed, E.M.; Abdallah, I.; Wahed, W. Acanthamoeba keratitis in noncompliant soft contact lenses users: Genotyping and risk factors, a study from Cairo, Egypt. J. Infect. Public Health 2018, 11, 377-383. [CrossRef]

15. Marciano-Cabral, F.; Cabral, G. Acanthamoeba spp. as agents of disease in humans. Clin. Microbiol. Rev. 2003, 16, 273-307. [CrossRef]

16. Henriquez, F.L.; Mooney, R.; Bandel, T.; Giammarini, E.; Zeroual, M.; Fiori, P.L.; Margarita, V.; Rappelli, P.; Dessì, D. Paradigms of protist/bacteria symbiosis affecting human health: Acanthamoeba species and Trichomonas vaginalis. Front. Microbiol. 2020, 11,3380.

17. Scheid, P.; Schwarzenberger, R. Acanthamoeba spp. as vehicle and reservoir of adenoviruses. Parasitol. Res. 2012, 111, 479-485. [CrossRef]

18. Guimaraes, A.J.; Gomes, K.X.; Cortines, J.R.; Peralta, J.M.; Peralta, R.H. Acanthamoeba spp. as a universal host for pathogenic microorganisms: One bridge from environment to host virulence. Microbiol. Res. 2016, 193, 30-38. [CrossRef]

19. Clarke, M.; Lohan, A.J.; Liu, B.; Lagkouvardos, I.; Roy, S.; Zafar, N.; Bertelli, C.; Schilde, C.; Kianianmomeni, A.; Bürglin, T.R.; et al. Genome of Acanthamoeba castellanii highlights extensive lateral gene transfer and early evolution of tyrosine kinase signaling. Genome Biol. 2013, 14, 1-15. [CrossRef]

20. Fritsche, T.; Gautom, R.; Seyedirashti, S.; Bergeron, D.; Lindquist, T.D. Occurrence of bacterial endosymbionts in Acanthamoeba spp. isolated from corneal and environmental specimens and contact lenses. J. Clin. Microbiol. 1993, 31, 1122-1126. [CrossRef]

21. Iovieno, A.; Ledee, D.R.; Miller, D.; Alfonso, E.C. Detection of bacterial endosymbionts in clinical Acanthamoeba isolates. Ophthalmology 2010, 117, 445-452.e443. [CrossRef]

22. Müller, A.; Walochnik, J.; Wagner, M.; Schmitz-Esser, S. A clinical Acanthamoeba isolate harboring two distinct bacterial endosymbionts. Eur. J. Protistol. 2016, 56, 21-25. [CrossRef] [PubMed]

23. Buchner, P. Endosymbiosis of Animals with Plant Microorganisms; John Wiley \& Sons: Hoboken, NJ, USA, 1965.

24. Scheid, P. Relevance of free-living amoebae as hosts for phylogenetically diverse microorganisms. Parasitol. Res. 2014, 113, 2407-2414. [CrossRef] [PubMed]

25. Scheid, P.; Hauröder, B.; Michel, R. Investigations of an extraordinary endocytobiont in Acanthamoeba sp.: Development and replication. Parasitol. Res. 2010, 106, 1371-1377. [CrossRef] [PubMed]

26. German, N.; Doyscher, D.; Rensing, C. Bacterial killing in macrophages and amoeba: Do they all use a brass dagger? Future Microbiol. 2013, 8, 1257-1264. [CrossRef]

27. Declerck, P.; Behets, J.; De Keersmaecker, B.; Ollevier, F. Receptor-mediated uptake of Legionella pneumophila by Acanthamoeba castellanii and Naegleria lovaniensis. J. Appl. Microbiol. 2007, 103, 2697-2703. [CrossRef] [PubMed]

28. Matz, C.; Nouri, B.; McCarter, L.; Martinez-Urtaza, J. Acquired type III secretion system determines environmental fitness of epidemic Vibrio parahaemolyticus in the interaction with bacterivorous protists. PLoS ONE 2011, 6, e20275. [CrossRef]

29. Siddiqui, R.; Malik, H.; Sagheer, M.; Jung, S.-Y.; Khan, N.A. The type III secretion system is involved in Escherichia coli K1 interactions with Acanthamoeba. Exp. Parasitol. 2011, 128, 409-413. [CrossRef]

30. Jung, S.-Y.; Matin, A.; Kim, K.S.; Khan, N.A. The capsule plays an important role in Escherichia coli K1 interactions with Acanthamoeba. Int. J. Parasitol. 2007, 37, 417-423. [CrossRef] 
31. Molmeret, M.; Horn, M.; Wagner, M.; Santic, M.; Kwaik, Y.A. Amoebae as training grounds for intracellular bacterial pathogens. Appl. Environ. Microbiol. 2005, 71, 20-28. [CrossRef]

32. Greub, G.; Raoult, D. Microorganisms resistant to free-living amoebae. Clin. Microbiol. Rev. 2004, 17, 413-433. [CrossRef] [PubMed]

33. Schmitz-Esser, S.; Toenshoff, E.R.; Haider, S.; Heinz, E.; Hoenninger, V.M.; Wagner, M.; Horn, M. Diversity of bacterial endosymbionts of environmental Acanthamoeba isolates. Appl. Environ. Microbiol. 2008, 74, 5822-5831. [CrossRef]

34. Espinoza-Vergara, G.; Hoque, M.M.; McDougald, D.; Noorian, P. The Impact of Protozoan Predation on the Pathogenicity of Vibrio cholerae. Front. Microbiol. 2020, 11, 17. [CrossRef] [PubMed]

35. Maumus, F.; Blanc, G. Study of gene trafficking between Acanthamoeba and giant viruses suggests an undiscovered family of amoeba-infecting viruses. Genome Biol. Evol. 2016, 8, 3351-3363. [CrossRef] [PubMed]

36. Hervet, E.; Charpentier, X.; Vianney, A.; Lazzaroni, J.-C.; Gilbert, C.; Atlan, D.; Doublet, P. Protein kinase LegK2 is a type IV secretion system effector involved in endoplasmic reticulum recruitment and intracellular replication of Legionella pneumophila. Infect. Immun. 2011, 79, 1936-1950. [CrossRef] [PubMed]

37. Thomas, V.; McDonnell, G.; Denyer, S.P.; Maillard, J.-Y.J. Free-living amoebae and their intracellular pathogenic microorganisms: Risks for water quality. FEMS. Microbiol. Rev. 2010, 34, 231-259. [CrossRef] [PubMed]

38. Fritsche, T.R.; Sobek, D.; Gautom, R.K. Enhancement of in vitro cytopathogenicity by Acanthamoeba spp. following acquisition of bacterial endosymbionts. FEMS. Microbiol. Lett. 1998, 166, 231-236. [CrossRef]

39. Bozue, J.A.; Johnson, W. Interaction of Legionella pneumophila with Acanthamoeba castellanii: Uptake by coiling phagocytosis and inhibition of phagosome-lysosome fusion. Infect. Immun. 1996, 64, 668-673. [CrossRef]

40. Yagita, K.; Matias, R.; Yasuda, T.; Natividad, F.; Enriquez, G.; Endo, T. Acanthamoeba sp. from the Philippines: Electron microscopy studies on naturally occurring bacterial symbionts. Parasitol. Res. 1995, 81, 98-102. [CrossRef] [PubMed]

41. Chung, D.I.; Kong, H.H.; Kim, T.H.; Hwang, M.Y.; Yu, H.S.; Yun, H.C.; Seol, S.Y. Bacterial endosymbiosis within the cytoplasm of Acanthamoeba lugdunensis isolated from a contact lens storage case. Korean J. Parasitol. 1997, 35, 127-133. [CrossRef]

42. Amann, R.; Springer, N.; Schönhuber, W.; Ludwig, W.; Schmid, E.N.; Müller, K.; Michel, R. microbiology, e. Obligate intracellular bacterial parasites of acanthamoebae related to Chlamydia spp. Appl. Environ. Microbiol. 1997, 63, 115-121. [CrossRef]

43. Michel, R.; Hauröder, B. Isolation of an Acanthamoeba strain with intracellular Burkholderia pickettii infection. Int. J. Med Microbiol. 1997, 285, 541-557. [CrossRef]

44. Michel, R.; Müller, K.-D.; Amann, R.; Schmid, E.N. Legionella-like slender rods multiplying within a strain of Acanthamoeba sp. isolated from drinking water. Parasitol. Res. 1997, 84, 84-88. [CrossRef] [PubMed]

45. Hoffmann, R.; Michel, R.; Muller, K.-D.; Schmid, E.N. Archaea like endocytobiotic organisms isolated from Acanthamoeba SP (GR II). Endocytobiosis Cell Res. 1998, 12, 185-188.

46. Mölled, K.-D.; Schmid, E.N.; Michel, R. Intracellular Bacteria of Acanthamoebae Resembling Legionella spp. Turned Out to be Cytophaga sp. Int. J. Med Microbiol. 1999, 289, 389-397.

47. Horn, M.; Fritsche, T.R.; Gautom, R.K.; Schleifer, K.H.; Wagner, M. Novel bacterial endosymbionts of Acanthamoeba spp. related to the Paramecium caudatum symbiont Caedibacter caryophilus. Environ. Microbiol. 1999, 1, 357-367. [CrossRef]

48. Fritsche, T.R.; Horn, M.; Seyedirashti, S.; Gautom, R.K.; Schleifer, K.-H.; Wagner, M. In situ detection of novel bacterial endosymbionts of Acanthamoeba spp. phylogenetically related to members of the order Rickettsiales. Appl. Environ. Microbiol. 1999, 65, 206-212. [CrossRef]

49. Fritsche, T.R.; Horn, M.; Wagner, M.; Herwig, R.P.; Schleifer, K.-H.; Gautom, R.K. Phylogenetic diversity among geographically dispersed Chlamydiales endosymbionts recovered from clinical and environmental isolates of Acanthamoeba spp. Appl. Environ. Microbiol. 2000, 66, 2613-2619. [CrossRef]

50. Collingro, A.; Toenshoff, E.R.; Taylor, M.W.; Fritsche, T.R.; Wagner, M.; Horn, M. 'Candidatus Protochlamydia amoebophila', an endosymbiont of Acanthamoeba spp. Int. J. Syst. Evol. Microbiol. 2005, 55, 1863-1866. [CrossRef]

51. Birtles, R.; Rowbotham, T.; Michel, R.; Pitcher, D.; Lascola, B.; Alexiou-Daniel, S.; Raoult, D. ‘Candidatus Odyssella thessalonicensis' gen. nov., sp. nov., an obligate intracellular parasite of Acanthamoeba species. Int. J. Syst. Evol. Microbiol. 2000, $50,63-72$. [CrossRef]

52. Horn, M.; Harzenetter, M.D.; Linner, T.; Schmid, E.N.; Müller, K.D.; Michel, R.; Wagner, M. Members of the CytophagaFlavobacterium-Bacteroides phylum as intracellular bacteria of acanthamoebae: Proposal of 'Candidatus Amoebophilus asiaticus'. Environ. Microbiol. 2001, 3, 440-449. [CrossRef] [PubMed]

53. Horn, M.; Fritsche, T.R.; Linner, T.; Gautom, R.K.; Harzenetter, M.D.; Wagner, M. Obligate bacterial endosymbionts of Acanthamoeba spp. related to the beta-Proteobacteria: Proposal of 'Candidatus Procabacter acanthamoebae'gen. nov., sp. nov. Int. J. Syst. Evol. Microbiol. 2002, 52, 599-605. [CrossRef]

54. La Scola, B.; Audic, S.; Robert, C.; Jungang, L.; de Lamballerie, X.; Drancourt, M.; Birtles, R.; Claverie, J.-M.; Raoult, D. A giant virus in amoebae. Science 2003, 299, 2033. [CrossRef]

55. Yu, H.S.; Jeong, H.J.; Hong, Y.-C.; Seol, S.-Y.; Chung, D.-I.; Kong, H.H. Natural occurrence of Mycobacterium as an endosymbiont of Acanthamoeba isolated from a contact lens storage case. Korean J. Parasitol. 2007, 45, 11. [CrossRef] [PubMed]

56. Xuan, Y.-H.; Yu, H.S.; Jeong, H.J.; Seol, S.-Y.; Chung, D.-I.; Kong, H.H. Molecular characterization of bacterial endosymbionts of Acanthamoeba isolates from infected corneas of Korean patients. Korean J. Parasitol. 2007, 45, 1. [CrossRef] 
57. Heinz, E.; Kolarov, I.; Kästner, C.; Toenshoff, E.R.; Wagner, M.; Horn, M. An Acanthamoeba sp. containing two phylogenetically different bacterial endosymbionts. Environ. Microbiol. 2007, 9, 1604-1609. [CrossRef]

58. Lorenzo-Morales, J.; Coronado-Álvarez, N.; Martínez-Carretero, E.; Maciver, S.K.; Valladares, B. Detection of four adenovirus serotypes within water-isolated strains of Acanthamoeba in the Canary Islands, Spain. Am. J. Trop. Med. Hyg. 2007, 77, 753-756. [CrossRef]

59. Scheid, P.; Zöller, L.; Pressmar, S.; Richard, G.; Michel, R. An extraordinary endocytobiont in Acanthamoeba sp. isolated from a patient with keratitis. Parasitol. Res. 2008, 102, 945-950. [CrossRef] [PubMed]

60. Antwerpen, M.; Georgi, E.; Zoeller, L.; Woelfel, R.; Stoecker, K.; Scheid, P. Whole-genome sequencing of a pandoravirus isolated from keratitis-inducing acanthamoeba. Genome Announc. 2015, 3. [CrossRef]

61. Choi, S.H.; Cho, M.K.; Ahn, S.C.; Lee, J.E.; Lee, J.S.; Kim, D.-H.; Xuan, Y.-H.; Hong, Y.C.; Kong, H.H.; Chung, D.I.; et al. Endosymbionts of Acanthamoeba isolated from domestic tap water in Korea. Korean J. Parasitol. 2009, 47, 337. [CrossRef] [PubMed]

62. Matsuo, J.; Kawaguchi, K.; Nakamura, S.; Hayashi, Y.; Yoshida, M.; Takahashi, K.; Mizutani, Y.; Yao, T.; Yamaguchi, H. Survival and transfer ability of phylogenetically diverse bacterial endosymbionts in environmental Acanthamoeba isolates. Environ. Microbiol. Rep. 2010, 2, 524-533. [CrossRef]

63. Okude, M.; Matsuo, J.; Nakamura, S.; Kawaguchi, K.; Hayashi, Y.; Sakai, H.; Yoshida, M.; Takahashi, K.; Yamaguchi, H. Environmental chlamydiae alter the growth speed and motility of host acanthamoebae. Microbes Environ. 2012, $27,423-429$. [CrossRef] [PubMed]

64. Corsaro, D.; Pages, G.S.; Catalan, V.; Loret, J.-F.; Greub, G. Biodiversity of amoebae and amoeba-associated bacteria in water treatment plants. Int. J. Hyg. Environ. Health 2010, 213, 158-166. [CrossRef] [PubMed]

65. Cohen, G.; Hoffart, L.; La Scola, B.; Raoult, D.; Drancourt, M. Ameba-associated keratitis, France. Emerg. Infect. Dis. 2011, 17, 1306. [CrossRef] [PubMed]

66. Glaser, K.C.; Hetrick, N.D.; Molestina, R.E. Evidence for a Previously Unrecognized Mycobacterial Endosymbiont in Acanthamoeba castellanii Strain Ma (ATCC ${ }^{\circledR} 50370^{\mathrm{TM}}$ ). J. Eukaryot. Microbiol. 2011, 58, 75-76. [CrossRef] [PubMed]

67. Gaze, W.H.; Morgan, G.; Zhang, L.; Wellington, E.M. Mimivirus-like particles in acanthamoebae from Sewage Sludge. Emerg. Infect. Dis. 2011, 17, 1127. [CrossRef]

68. Corsaro, D.; Müller, K.-D.; Michel, R. Molecular characterization and ultrastructure of a new amoeba endoparasite belonging to the Stenotrophomonas maltophilia complex. Exp. Parasitol. 2013, 133, 383-390. [CrossRef]

69. Sampo, A.; Matsuo, J.; Yamane, C.; Yagita, K.; Nakamura, S.; Shouji, N.; Hayashi, Y.; Yamazaki, T.; Yoshida, M.; Kobayashi, M.; et al. High-temperature adapted primitive Protochlamydia found in Acanthamoeba isolated from a hot spring can grow in immortalized human epithelial HEp-2 cells. Environ. Microbiol. 2014, 16, 486-497. [CrossRef]

70. Lagkouvardos, I.; Shen, J.; Horn, M. Improved axenization method reveals complexity of symbiotic associations between bacteria and acanthamoebae. Environ. Microbiol. Rep. 2014, 6, 383-388. [CrossRef]

71. Maschio, V.J.; Corção, G.; Bücker, F.; Caumo, K.; Rott, M.B. Identification of Paenibacillus as a Symbiont in Acanthamoeba. Curr. Microbiol. 2015, 71, 415-420. [CrossRef]

72. José Maschio, V.; Corção, G.; Rott, M.B. Identification of Pseudomonas spp. as amoeba-resistant microorganisms in isolates of Acanthamoeba. Rev. Inst. Med. Trop. São Paulo 2015, 57, 81-83.

73. Nakagawa, H.; Hattori, T.; Koike, N.; Ehara, T.; Fujita, K.; Takahashi, H.; Kumakura, S.; Kuroda, M.; Matsumoto, T.; Goto, H. Investigation of the role of bacteria in the development of Acanthamoeba keratitis. Cornea 2015, 34, 1308-1315. [CrossRef]

74. Niyyati, M.; Mahyar, M.; Haghighi, A.; Vala, M.H. Occurrence of Potentially Pathogenic Bacterial-Endosymbionts in Acanthamoeba spp. J. Iran. J. Parasitol. 2015, 10, 181.

75. Magnet, A.; Peralta, R.; Gomes, T.; Izquierdo, F.; Fernandez-Vadillo, C.; Galvan, A.; Pozuelo, M.; Pelaz, C.; Fenoy, S.; Del Águila, C. Vectorial role of Acanthamoeba in Legionella propagation in water for human use. Sci. Total Environ. 2015, 505, 889-895. [CrossRef] [PubMed]

76. Fukumoto, T.; Matsuo, J.; Okubo, T.; Nakamura, S.; Miyamoto, K.; Oka, K.; Takahashi, M.; Akizawa, K.; Shibuya, H.; Shimizu, C.; et al. Acanthamoeba containing endosymbiotic chlamydia isolated from hospital environments and its potential role in inflammatory exacerbation. BMC Microbiol. 2016, 16, 292. [CrossRef]

77. Scheikl, U.; Tsao, H.-F.; Horn, M.; Indra, A.; Walochnik, J. Free-living amoebae and their associated bacteria in Austrian cooling towers: A 1-year routine screening. Parasitol. Res. 2016, 115, 3365-3374. [CrossRef]

78. Purssell, A.; Lau, R.; Boggild, A.K. Azithromycin and doxycycline attenuation of Acanthamoeba virulence in a human corneal tissue model. J. Infect. Dis. 2017, 215, 1303-1311. [PubMed]

79. Faizah, M.; Anisah, N.; Yusof, S.; Noraina, A.; Adibah, M.R. Molecular detection of bacterial endosymbionts in Acanthamoeba spp.: A preliminary study. Med Health 2017, 12, 286-292.

80. Chan, L.L.; Mak, J.W.; Ambu, S.; Chong, P.Y. Identification and ultrastructural characterization of Acanthamoeba bacterial endocytobionts belonging to the Alphaproteobacteria class. PLoS ONE 2018, 13, e0204732. [CrossRef]

81. Hajialilo, E.; Rezaeian, M.; Niyyati, M.; Pourmand, M.R.; Mohebali, M.; Norouzi, M.; Pashabeyg, K.R.; Rezaie, S.; Khodavaisy, S. Molecular characterization of bacterial, viral and fungal endosymbionts of Acanthamoeba isolates in keratitis patients of Iran. Exp. Parasitol. 2019, 200, 48-54. [CrossRef] [PubMed]

82. Jensen, T.; Barnes, W.G.; Meyers, D. Axenic cultivation of large populations of Acanthamoeba castellanii (JBM). J. Parasitol. 1970, 56, 904-906. [CrossRef] 
83. De Moraes, J.; Alfieri, S.C. Growth, encystment and survival of Acanthamoeba castellanii grazing on different bacteria. FEMS. Microbiol. Ecol. 2008, 66, 221-229. [CrossRef] [PubMed]

84. de Lacerda, A.G.; Lira, M. Acanthamoeba keratitis: A review of biology, pathophysiology and epidemiology. Ophthalmic Physiol. Opt. 2021, 41, 116-135. [CrossRef] [PubMed]

85. Neff, R.J. Mechanisms of purifying amoebae by migration on agar surfaces. J. Protozool. 1958, 5, 226-231. [CrossRef]

86. Neff, R.J. Purification, axenic cultivation, and description of a soil amoeba, Acanthamoeba sp. J. Protozool. 1957, 4, 176-182. [CrossRef]

87. Niyyati, M.; Abedkhojasteh, H.; Salehi, M.; Farnia, S.; Rezaeian, M. Axenic cultivation and pathogenic assays of acanthamoeba strains using physical parameters. Iran. J. Parasitol. 2013, 8, 186. [PubMed]

88. Khan, N.A. Acanthamoeba: Biology and increasing importance in human health. FEMS. Microbiol. Rev. 2006, 30, 564-595. [CrossRef]

89. Kilvington, S.; Larkin, D.; White, D.; Beeching, J.R. Laboratory investigation of Acanthamoeba keratitis. J. Clin. Microbiol. 1990, 28, 2722-2725. [CrossRef] [PubMed]

90. Eroğlu, F.; Evyapan, G.; Koltaş, İ.S. The cultivation of Acanthamoeba using with different axenic and monoxenic media. Middle Black Sea J. Health Sci. 2015, 1, 13-17. [CrossRef]

91. Huws, S.A.; Morley, R.J.; Jones, M.V.; Brown, M.R.; Smith, A.W. Interactions of some common pathogenic bacteria with Acanthamoeba polyphaga. FEMS. Microbiol. Lett. 2008, 282, 258-265. [CrossRef]

92. Todd, C.D.; Reyes-Batlle, M.; Martín-Navarro, C.M.; Dorta-Gorrín, A.; López-Arencibia, A.; Martínez-Carretero, E.; Piñero, J.E.; Valladares, B.; Lindo, J.F.; Lorenzo-Morales, J. Isolation and genotyping of Acanthamoeba strains from soil sources from Jamaica, West Indies. J. Eukaryot. Microbiol. 2015, 62, 416-421. [CrossRef]

93. Pagnier, I.; Raoult, D.; La Scola, B. Isolation and identification of amoeba-resisting bacteria from water in human environment by using an Acanthamoeba polyphaga co-culture procedure. Environ. Microbiol. 2008, 10, 1135-1144. [CrossRef] [PubMed]

94. Collingro, A.; Poppert, S.; Heinz, E.; Schmitz-Esser, S.; Essig, A.; Schweikert, M.; Wagner, M.; Horn, M. Recovery of an environmental chlamydia strain from activated sludge by co-cultivation with Acanthamoeba sp. Microbiology 2005, 151, 301-309. [CrossRef]

95. Thomas, V.; Casson, N.; Greub, G. Criblamydia sequanensis, a new intracellular Chlamydiales isolated from Seine river water using amoebal co-culture. J. Environ. Microbiol. 2006, 8, 2125-2135. [CrossRef]

96. Saeed, A.; Abd, H.; Edvinsson, B.; Sandström, G. Acanthamoeba castellanii an environmental host for Shigella dysenteriae and Shigella sonnei. Arch. Microbiol. 2009, 191, 83. [CrossRef]

97. Axelsson-Olsson, D.; Waldenström, J.; Broman, T.; Olsen, B.; Holmberg, M. Protozoan Acanthamoeba polyphaga as a potential reservoir for Campylobacter jejuni. Appl. Environ. Microbiol. 2005, 71, 987-992. [CrossRef] [PubMed]

98. Steinert, M.; Emödy, L.; Amann, R.; Hacker, J.; Microbiology, E. Resuscitation of viable but nonculturable Legionella pneumophila Philadelphia JR32 by Acanthamoeba castellanii. Appl. Environ. Microbiol. 1997, 63, 2047-2053. [CrossRef]

99. Axelsson-Olsson, D.; Ellström, P.; Waldenström, J.; Haemig, P.D.; Brudin, L.; Olsen, B. Acanthamoeba-Campylobacter coculture as a novel method for enrichment of Campylobacter species. Appl. Environ. Microbiol. 2007, 73, 6864-6869. [CrossRef] [PubMed]

100. Dey, R.; Rieger, A.M.; Stephens, C.; Ashbolt, N.J. Interactions of pseudomonas aeruginosa with Acanthamoeba polyphaga observed by imaging flow cytometry. Cytom. A 2019, 95, 555-564. [CrossRef] [PubMed]

101. Abd, H.; Johansson, T.; Golovliov, I.; Sandström, G.; Forsman, M. Survival and growth of Francisella tularensis in Acanthamoeba castellanii. J Appl. Environ. Microbiol. 2003, 69, 600-606. [CrossRef]

102. Van der Henst, C.; Scrignari, T.; Maclachlan, C.; Blokesch, M. An intracellular replication niche for Vibrio cholerae in the amoeba Acanthamoeba castellanii. ISME J. 2016, 10, 897-910. [CrossRef]

103. El-Etr, S.H.; Margolis, J.J.; Monack, D.; Robison, R.A.; Cohen, M.; Moore, E.; Rasley, A. Francisella tularensis type A strains cause the rapid encystment of Acanthamoeba castellanii and survive in amoebal cysts for three weeks postinfection. J. Appl. Environ. Microbiol. 2009, 75, 7488-7500. [CrossRef]

104. Hojo, F.; Osaki, T.; Yonezawa, H.; Hanawa, T.; Kurata, S.; Kamiya, S. Acanthamoeba castellanii supports extracellular survival of Helicobacter pylori in co-culture. J. Infect. Chemother. 2020, 26, 946-954. [CrossRef]

105. Dey, R.; Hoffman, P.S.; Glomski, I.J. Germination and amplification of anthrax spores by soil-dwelling amoebas. J. Appl. Environ. Microbiol. 2012, 78, 8075-8081. [CrossRef] [PubMed]

106. Steenbergen, J.N.; Nosanchuk, J.D.; Malliaris, S.D.; Casadevall, A. Interaction of Blastomyces dermatitidis, Sporothrix schenckii, and Histoplasma capsulatum with Acanthamoeba castellanii. Infect. Immun. 2004, 72, 3478-3488. [CrossRef] [PubMed]

107. Steenbergen, J.; Shuman, H.; Casadevall, A. Cryptococcus neoformans interactions with amoebae suggest an explanation for its virulence and intracellular pathogenic strategy in macrophages. Proc. Natl. Acad. Sci. USA 2001, 98, 15245-15250. [CrossRef]

108. Nunes, T.E.T.; Brazil, N.T.; Fuentefria, A.M.; Rott, M.B. Acanthamoeba and Fusarium interactions: A possible problem in keratitis. Acta Trop. 2016, 157, 102-107. [CrossRef] [PubMed]

109. Mattana, A.; Serra, C.; Mariotti, E.; Delogu, G.; Fiori, P.L.; Cappuccinelli, P. Acanthamoeba castellanii promotion of in vitro survival and transmission of coxsackie b3 viruses. Eukaryot. Cell 2006, 5, 665-671. [CrossRef]

110. Yamaguchi, H.; Matsuo, J.; Yamazaki, T.; Ishida, K.; Yagita, K. Draft genome sequence of high-temperature-adapted Protochlamydia sp. HS-T3, an amoebal endosymbiotic bacterium found in Acanthamoeba Isolated from a hot spring in Japan. Genome Announc. 2015, 3. [CrossRef] 
111. Wang, Z.; Wu, M. Complete genome sequence of the endosymbiont of Acanthamoeba strain UWC8, an amoeba endosymbiont belonging to the "Candidatus Midichloriaceae" family in Rickettsiales. Genome Announc. 2014, 2. [CrossRef]

112. Hsia, Y.C.; Leal, S.M., Jr.; Booton, G.C.; Joslin, C.E.; Cianciotto, N.P.; Tu, E.Y.; Pearlman, E. Acanthamoeba Keratitis Is Exacerbated In The Presence Of Intracellular Legionella Pneumophila. Investig. Ophthalmol. Vis. Sci. 2011, 52, 5794.

113. Johnston, S.P.; Sriram, R.; Qvarnstrom, Y.; Roy, S.; Verani, J.; Yoder, J.; Lorick, S.; Roberts, J.; Beach, M.J.; Visvesvara, G. Resistance of Acanthamoeba cysts to disinfection in multiple contact lens solutions. J. Clin. Microbiol. 2009, 47, 2040-2045. [CrossRef]

114. Verani, J.R.; Lorick, S.A.; Yoder, J.S.; Beach, M.J.; Braden, C.R.; Roberts, J.M.; Conover, C.S.; Chen, S.; McConnell, K.A.; Chang, D.C.; et al. National outbreak of Acanthamoeba keratitis associated with use of a contact lens solution, United States. Emerg. Infect. Dis. 2009, 15, 1236. [CrossRef]

115. Carnt, N.; Hoffman, J.J.; Verma, S.; Hau, S.; Radford, C.F.; Minassian, D.C.; Dart, J.K. Acanthamoeba keratitis: Confirmation of the UK outbreak and a prospective case-control study identifying contributing risk factors. Br. J. Ophthalmol. 2018, 102, 1621-1628. [CrossRef]

116. Scheikl, U.; Sommer, R.; Kirschner, A.; Rameder, A.; Schrammel, B.; Zweimüller, I.; Wesner, W.; Hinker, M.; Walochnik, J. Free-living amoebae (FLA) co-occurring with legionellae in industrial waters. Eur. J. Protistol. 2014, 50, 422-429. [CrossRef]

117. Albert-Weissenberger, C.; Cazalet, C.; Buchrieser, C. Legionella pneumophila-A human pathogen that co-evolved with freshwater protozoa. Cell. Mol. Life Sci. 2007, 64, 432-448. [CrossRef]

118. Barker, J.; Brown, M.R.W. Trojan horses of the microbial world: Protozoa and the survival of bacterial pathogens in the environment. Microbiology 1994, 140, 1253-1259. [CrossRef] [PubMed]

119. Koltas, I.S.; Eroglu, F.; Erdem, E.; Yagmur, M.; Tanır, F. The role of domestic tap water on Acanthamoeba keratitis in non-contact lens wearers and validation of laboratory methods. Parasitol. Res. 2015, 114, 3283-3289. [CrossRef] [PubMed]

120. Zimmerman, A.B.; Richdale, K.; Mitchell, G.L.; Kinoshita, B.T.; Lam, D.Y.; Wagner, H.; Sorbara, L.; Chalmers, R.L.; Collier, S.A.; Cope, J.R. Water exposure is a common risk behavior among soft and gas-permeable contact lens wearers. Cornea 2017, $36,995$. [CrossRef] [PubMed]

121. Kilvington, S.; Gray, T.; Dart, J.; Morlet, N.; Beeching, J.R.; Frazer, D.G.; Matheson, M. Acanthamoeba keratitis: The role of domestic tap water contamination in the United Kingdom. Investig. Ophthalmol. Vis. Sci. 2004, 45, 165-169. [CrossRef]

122. Jeong, H.J.; Yu, H.S. The role of domestic tap water in Acanthamoeba contamination in contact lens storage cases in Korea. Korean J. Parasitol. 2005, 43, 47. [CrossRef] [PubMed]

123. Mura, M.; Bull, T.J.; Evans, H.; Sidi-Boumedine, K.; McMinn, L.; Rhodes, G.; Pickup, R.; Hermon-Taylor, J. Replication and longterm persistence of bovine and human strains of Mycobacterium avium subsp. paratuberculosis within Acanthamoeba polyphaga. Appl. Environ. Microbiol. 2006, 72, 854-859. [CrossRef]

124. Berk, S.G.; Ting, R.S.; Turner, G.W.; Ashburn, R.J.; Microbiology, E. Production of Respirable Vesicles Containing LiveLegionella pneumophila Cells by Two Acanthamoeba spp. Appl. Environ. Microbiol. 1998, 64, 279-286. [CrossRef]

125. Chekabab, S.M.; Daigle, F.; Charette, S.J.; Dozois, C.M.; Harel, J. Shiga toxins decrease enterohaemorrhagic Escherichia coli survival within Acanthamoeba castellanii. FEMS. Microbiol. Letters. 2013, 344, 86-93. [CrossRef] [PubMed]

126. Schmitz-Esser, S.; Linka, N.; Collingro, A.; Beier, C.L.; Neuhaus, H.E.; Wagner, M.; Horn, M. ATP/ADP translocases: A common feature of obligate intracellular amoebal symbionts related to Chlamydiae and Rickettsiae. J. Bacteriol. 2004, 186, 683-691. [CrossRef] [PubMed]

127. Siddiqui, R.; Khan, N.A. War of the microbial worlds: Who is the beneficiary in Acanthamoeba-bacterial interactions? Exp. Parasitol. 2012, 130, 311-313. [CrossRef] [PubMed]

128. Segal, G.; Shuman, H.A. Legionella pneumophila utilizes the same genes to multiply within Acanthamoeba castellanii and human macrophages. Infect. Immun. 1999, 67, 2117-2124. [CrossRef] [PubMed]

129. Best, A.; Price, C.; Ozanic, M.; Santic, M.; Jones, S.; Kwaik, Y.A. A Legionella pneumophila amylase is essential for intracellular replication in human macrophages and amoebae. Sci. Rep. 2018, 8, 1-12. [CrossRef]

130. Ogata, H.; La Scola, B.; Audic, S.; Renesto, P.; Blanc, G.; Robert, C.; Fournier, P.-E.; Claverie, J.-M.; Raoult, D. Genome sequence of Rickettsia bellii illuminates the role of amoebae in gene exchanges between intracellular pathogens. PLoS Genet. 2006,2 , e76. [CrossRef] [PubMed]

131. Moher, D.; Liberati, A.; Tetzlaff, J.; Altman, D.G.; Group, P. Preferred reporting items for systematic reviews and meta-analyses: The PRISMA statement. PLoS Med. 2009, 6, e1000097. [CrossRef]

132. Stang, A. Critical evaluation of the Newcastle-Ottawa scale for the assessment of the quality of nonrandomized studies in meta-analyses. J. Eur. J. Epidemiol. 2010, 25, 603-605. [CrossRef]

133. Wang, C.; Ye, C.; Liao, L.; Wang, Z.; Hu, Y.; Deng, C.; Liu, L. Adjuvant $\beta$-lactam therapy combined with vancomycin or daptomycin for methicillin-resistant Staphylococcus aureus bacteraemia: A systematic review and meta-analysis. Antimicrob. Agents Chemother. 2020, 64, 11. [CrossRef] [PubMed] 